\title{
Investor Protection and Income Inequality: Risk Sharing vs Risk Taking*
}

\author{
Alessandra Bonfiglioli ${ }^{\dagger}$ \\ Institute for Economic Analysis-CSIC and CEPR
}

May 17, 2010

\begin{abstract}
This paper studies the relationship between investor protection, entrepreneurial risk taking and income inequality. In the presence of market frictions, better protection makes investors more willing to take on entrepreneurial risk when lending to firms, thereby improving the degree of risk sharing between financiers and entrepreneurs. On the other hand, by increasing risk sharing, investor protection also induces more firms to undertake risky projects. By increasing entrepreneurial risk taking, it raises income dispersion. By reducing the risk faced by entrepreneurs, it reduces income volatility. As a result, investor protection raises income inequality to the extent that it fosters risk taking, while it reduces it for a given level of risk taking. Empirical evidence from a panel of forty-five countries spanning the period 1976-2000 supports the predictions of the model.
\end{abstract}

JEL Classification: D31, E44, O16

Keywords: Investor protection, income inequality, optimal financial contracts, risk taking, risk sharing.

*I thank for their useful comments: Philippe Aghion, Francesco Caselli, Amparo Castelló Climent, Antonio Ciccone, Giovanni Favara, Gino Gancia, Nicola Gennaioli, Gita Gopinath, John Hassler, Ross Levine, Torsten Persson, Andrei Shleifer, Jaume Ventura, Fabrizio Zilibotti and seminar participants at Banco de España, Bocconi University, CREI and UPF, European Central Bank, IAE-CSIC, IIES, SIFR, Universitaat van Amsterdam-Timbergen Institute, Universidad Carlos III de Madrid, Universitat Autonoma de Barcelona, University of Warwick, the 2007 NBER Summer Institute (Capital Markets and the Economy), 2006 Annual Meeting of the European Economic Association, 2006 CEPR European Summer Symposium on International Macroeconomics, 2004 Annual Meeting of the Society for Economic Dynamics, 2004 European Winter Meeting of the Econometric Society. The support of the Spanish Ministry of Education and Science (grant ECO2008-04785) and of the Barcelona GSE research network and Generalitat de Catalunya (grant 2009 SGR 1126) is gratefully aknowledged. All remaining errors are mine.

${ }^{\dagger}$ Address: Institute for Economic Analysis-CSIC, Campus UAB, 08193 Bellaterra, Barcelona, Spain. E-mail: alessandra.bonfiglioli@iae.csic.es. 


\section{INTRODUCTION}

The literature on institutions, law and economics has shown that investor protection affects significantly the financial structure of an economy, and has investigated the effects of financial development on economic performance in terms of GDP growth, productivity and investment. ${ }^{1}$ What has not been recognized is that investor protection, through its effect on financial structure and the allocation of risk, may influence the risk taking behavior of investors and firms, thereby affecting income inequality. To fill this gap, this paper investigates the link between investor protection and income inequality, both theoretically and empirically. It proposes a model where investor protection promotes risk sharing between financiers and entrepreneurs, thereby inducing more risk taking in the economy. Better risk sharing and wider risk taking, in turn, affect income inequality in opposite ways. The main results of the model are then confronted with the data.

To formalize these ideas, I construct a simple model of investors and entrepreneurs where agents are risk averse and heterogeneous in ability. Investors decide how to allocate their endowment between safe loans and diversified portfolios of risky assets, while entrepreneurs face a choice between a safe and a risky technology, whose probability of success depends on ability. Starting up a firm entails a fixed entry cost that entrepreneurs must cover by borrowing. Financial markets are subject to a moral hazard problem arising from the non-observability of output to financiers. Measures of investor protection can be adopted to alleviate the financial friction. In particular, I assume that investor protection promotes transparency by imposing a proportional cost to misreport cash flow. ${ }^{2}$ For instance, this cost can be thought of as the additional honorary an auditor would charge to certify a falsified book or to design financial operations to hide revenues from outside financiers. Financial contracts are designed to be optimal and incentive compatible. Better guarantees generate more confidence among investors, thereby making them more willing to insure the entrepreneurs through lending. It follows that financial systems with stronger investor protection provide entrepreneurs with a higher degree of risk sharing. Finally, I rule out wealth heterogeneity among agents, so that all inequality is due to idiosyncratic factors (ability), financial market conditions and income risk. ${ }^{3}$

In the model, better investor protection affects income inequality in two ways.

\footnotetext{
${ }^{1}$ See, among others, Acemoglu and Johnson (2005), La Porta et al. (1997) and (2006), Beck and Levine (2004), Levine (2005) and references therein.

${ }^{2}$ Investor protection takes the form of a hiding cost also in Aghion et al. (2005), Castro et al. (2004) and Lacker and Weinberg (1989). In this paper, like in the two latter, the cost is proportional to the hidden amount, while in the first, it equals a fraction of the initial investment.

${ }^{3}$ As shown in Hurst and Lusardi (2004), wealth may not be the key factor affecting entrepreneurial choices. Abstracting from wealth heterogeneity allows me to better focus on other determinants, such as risk and ability.
} 
It improves risk sharing, thereby reducing income volatility for a given mass of agents operating the risky technology; and (ii) it raises the share of entrepreneurs choosing the risky option, and therefore being exposed to earning risk. While (i) tends to reduce inequality, (ii) raises it. It can be shown that the "risk taking" effect (ii) dominates when investor protection is low since risky entrepreneurs still face a considerable earnings risk, while the "risk sharing" effect (i) prevails when investor protection is high since better insurance applies to a large mass of risky entrepreneurs. Hence, the relationship between investor protection and income inequality is predicted to be non-monotonic.

To evaluate empirically the main results of the model, I consider a panel of fortyfive countries observed between 1976 and 2000. The choice of a cross-country analysis is dictated by the fact that investor protection is generally set by law and hence exhibits very little within-country variation. I evaluate the "risk sharing" and "risk taking" effects of investor protection first by controlling separately for investor protection and a proxy of risk taking. Next, I also control for the interaction between these variables. A major challenge of the empirical part is to find appropriate measures of the relevant variables. I proxy inequality with the Gini coefficient of the income distribution and investor protection with de jure indexes compiled by La Porta et al. (2006). While de jure indicators of investor protection are available and widely used, entrepreneurial risk taking is difficult to quantify. It was shown by the corporate finance literature that a firm relying more on external equity relative to debt finance is in a better position to embark in risky projects such as innovation (see for instance Brown et al., 2009). Therefore, I proxy risk taking with the ratio between stock market capitalization and credit to the private sector. The results suggest that indeed investor protection promotes risk taking, which in turn raises income inequality. Income dispersion, on the other hand, tends to fall with investor protection to the extent that this is not accompanied by more risk taking. This evidence lends support to the main theoretical predictions.

The contribution of this paper is related to four main strands of literature. Acemoglu and Johnson (2005), as well as La Porta et al. (1997, 1998, 1999, 2006), show that investor protection, and in general institutions aimed at contracting protection, affect the financial structure of an economy by promoting the development of stock markets, but have unclear effects on economic performance. No attention was devoted, however, to study the effects on inequality.

A recent literature on the macroeconomic implications of entrepreneurship addresses the effects of financial frictions on investment, growth and wealth concentration through their impact on entrepreneurial choices (see Quadrini, 2010 for a review). A series of papers suggest that the existence of financial frictions allows only the wealthiest agents 
to become entrepreneurs and induces them to save more in order to overcome the credit constraint and enlarge the firm in the future. This implies that wealth tends to become more concentrated (i.e., higher inequality) the more severe the financial friction. Aggregate capital accumulation may be slowed down due to imperfect risk sharing. The overall effect on growth may be ambiguous, and depend for instance on capital mobility, as in Castro et al. (2004). Caselli and Gennaioli (2005) show that weak contract enforcement deteriorates productivity (TFP) by discouraging untalented family-firm owners from hiring competent managers (as in Burkart et al., 2003). Michelacci and Schivardi (2010) show that, if firms cannot diversify away their idiosyncratic risk due to financial frictions, there is less risk taking and this has negative effects on growth. While some of these studies have considered the impact on inequality, they focus mainly on how financial frictions interact with initial wealth inequality in affecting entrepreneurial choices and in shaping the evolution of wealth distribution.

Theoretical contributions by Aghion and Bolton (1997), Banerjee and Newman (1993), Galor and Zeira (1993), Greenwood and Jovanovic (1990), and Piketty (1997), among others, have proposed explanations for the relationship between financial development, inequality and growth. In most of these models, income inequality originates from heterogeneity in the initial wealth distribution, paired with credit market frictions. As the poorest are subject to credit constraints, they are prevented from making efficient investments in the most productive activities. ${ }^{4}$ Over time, capital accumulation determines the dynamics of wealth and income. I depart from this approach in two main respects. First, the financial friction affects the share of risk borne by agents, rather than the amount of external finance available to them. Second, I consider a different source of ex-ante heterogeneity (entrepreneurial ability), and propose a new mechanism translating differences in ability into income inequality that is independent of wealth accumulation. In the present paper, heterogeneity in productivity, the extent of risk sharing and the size of the risky sector ultimately determine the income distribution. ${ }^{5}$ The implication is that, by promoting risk taking, better financial institutions can amplify inequality. This novel prediction is supported by the empirical evidence in the paper.

The vast empirical literature on financial development and economic performance (see Levine, 2005 and references therein) provides evidence that deeper financial markets foster growth. Very little attention was paid to the effects of financial development on income

\footnotetext{
${ }^{4}$ The credit constraint can derive from the non-observability of physical output as in Banerjee and Newman (1992) and Galor and Zeira (1993), or effort as in Aghion and Bolton (1997) and Piketty (1997).

${ }^{5}$ Similarly to this paper, in Acemoglu and Zilibotti (1999) income inequality is generated by managerial incentives. Antunes et al. (2008) propose a quantitative model with heterogeneity in wealth and ability where weak financial institutions hinder growth and raise income inequality. Yet, both papers abstract from firm-specific idiosyncratic risk.
} 
inequality. Two recent contributions (see Clarke et al., 2006 and Beck et al., 2007) show that higher availability of credit to the private sector, tends to reduce income inequality. My results are consistent with this evidence, but also provide a novel insight suggesting that equity-like finance, promoting risk taking, may actually increase inequality.

The remainder of the paper is organized as follows. Section 2 presents the model of entrepreneurial choice and shows how earnings and the degree of risk taking vary in equilibrium with investor protection. In section 3 , I characterize analytically and by means of numerical solution how income inequality responds to changes in investor protection and the degree of risk taking. Section 4 provides empirical evidence from a panel of fortyfive countries over the period 1976-2000 supporting the main results of the model. Section 5 concludes.

\section{The MOdeL}

In this section, I propose a simple static model where risk-averse agents, heterogeneous in their entrepreneurial ability, have to choose between safe and risky projects and need external finance. Asymmetric information in the financial market generates a moral hazard problem that makes it too costly for some entrepreneurs to finance risky projects. Investor protection may alleviate moral hazard, thereby easing the conditions of access to finance and promoting both risk sharing and risk taking.

\subsection{SET UP}

Consider a small open economy populated by a continuum of risk-averse agents whose preferences are represented by

$$
V=\mathbb{E}[u(c)],
$$

where $\mathbb{E}$ is the expectation operator, $c$ is consumption of a homogeneous good, and the utility function satisfies the following properties: $u^{\prime}>0, u^{\prime \prime}<0$ and $\lim _{c \rightarrow 0} u^{\prime}(c)=\infty$.

Agents are heterogeneous in their ability, denoted by $\pi \in[0,1]$, drawn from a continuously differentiable distribution $G(\pi)$, but have no wealth endowment. They work as self-employed entrepreneurs and can choose to produce the consumption good using either a safe or a risky technology. Their consumption may be heterogeneous and depend on individual ability and technological choice. Capital needed for production may be raised on the international financial market, where a risk-free asset yielding a gross return $r$ is traded, along with risky assets that will be described later. The price of the consumption good and the safe interest rate are determined on the world market and are assumed to be constant and normalized to 1 . 


\subsubsection{Technology}

Each entrepreneur with ability $\pi$ can choose between a safe and a risky technology. The former generates a constant level of production which is independent of ability:

$$
y^{S}(\pi)=y^{S}=B
$$

The performance of firms using the risky technology depends on entrepreneurial ability. ${ }^{6}$ For simplicity, and without much loss of generality, I assume that ability only affects the probability of success and not the quantities produced. ${ }^{7}$ In particular, an entrepreneur with ability $\pi$, generates output

$$
y(\pi)= \begin{cases}y^{H}=A & \text { with probability } \pi \\ y^{L}=\varphi A & \text { with probability } 1-\pi\end{cases}
$$

where $\varphi \in(0,1)$ and $y^{H}$ and $y^{L}$ denote production in the good and bad state respectively. This implies that a firm's expected cash flow is $[\pi+(1-\pi) \varphi] A$, which is increasing in ability. Success is i.i.d. within each ability group, hence there is no aggregate risk and total production of entrepreneurs with ability $\pi$ equals $g(\pi)[\pi+(1-\pi) \varphi] A$. Moreover, I assume that, regardless of their technological choice, entrepreneurs have to pay a fixed entry cost of 1 that can be covered by raising funds on the international financial market.

\subsubsection{Financial market}

I assume that investors in the international financial market are atomistic and risk-averse, and have perfect information about the risk-free interest rate $(r=1)$, production technologies $(B, A$ and $\varphi)$, the individual ability of each entrepreneur $(\pi)$ and her technological choice, but cannot observe final output $(y)$.

The financial contract entails the (credible) commitment of the firm to repay after production a certain amount, possibly contingent on the realization of output that is reported. Since production functions and technological choices are public information, entrepreneurs using the safe technology are known to generate with certainty a cash flow of $B$ and thus face a fix repayment equal to the international gross risk-free rate, 1 , which

\footnotetext{
${ }^{6}$ See Schiller and Crewson (1997), and Fairly and Robb (2003) for empirical studies on the determinants of entrepreneurial success, mainly among small firms.

${ }^{7}$ Ability can be considered as playing a twofold role. It enhances the chance of succeeding in risky enterprises, as assumed in the model. But it may also raise productivity regardless of the technological choice. Introducing this second effect into the model would not affect the results.
} 
gives them a payoff of

$$
w^{S}=B-1
$$

The situation is different if the borrower runs a risky project. Once production has occurred, an unlucky entrepreneur can only report output $y^{L}=\varphi A$, and hence repay to investors the cash flow minus her earnings: $y^{L}-w^{L}(\pi)$. If successful, the entrepreneur may misreport the output realization and pretend to be in the bad state, in order to repay $y^{L}-w^{L}(\pi)$ instead of $y^{H}-w^{H}(\pi)$. However, I assume that measures of investor protection, specific to the borrower's country, make misreporting costly. For every unit of hidden cash flow, the firm incurs a cost $p \in[0,1]$, so that the payoff from misreporting is $w^{L}(\pi)+(1-p)\left(y^{H}-y^{L}\right)$. Truth-telling is rational as long as its value is at least equal to that of misreporting. Therefore, the financial contract $\left\{w^{H}(\pi), w^{L}(\pi)\right\}$ must satisfy the incentive compatibility (IC) constraint:

$$
u\left(w^{H}(\pi)\right) \geq u\left(w^{L}(\pi)+(1-p)\left(y^{H}-y^{L}\right)\right) .
$$

Financial contracts are set to maximize the entrepreneur's expected utility, $V^{R}(\pi)$, subject to the IC constraint and the outsiders' participation constraint. The latter requires that investors be indifferent between lending to all entrepreneurs with ability $\pi$, and buying the risk-free asset. ${ }^{8}$ Thus, the payoffs from the risky choice are determined as the solution to the optimal financial contract problem:

$$
\max _{w^{H}(\pi), w^{L}(\pi)} V^{R}(\pi) \equiv \pi u\left(w^{H}(\pi)\right)+(1-\pi) u\left(w^{L}(\pi)\right)
$$

subject to the incentive compatibility constraint:

$$
u\left(w^{H}(\pi)\right) \geq u\left(w^{L}(\pi)+(1-p)(1-\varphi) A\right)
$$

and investors' participation constraint:

$$
\pi\left(A-w^{H}(\pi)\right)+(1-\pi)\left(\varphi A-w^{L}(\pi)\right)=1 .
$$

Note that a pooled portfolio of loans to the i.i.d. entrepreneurs with ability $\pi$ yields the LHS of (PC) with certainty, so that investors face no uncertainty. ${ }^{9}$

\footnotetext{
${ }^{8}$ See Castro et al. (2004) for a similar way of modelling the optimal financial contact.

${ }^{9}$ It follows that the participation constraint is the same as in the case of competitive, risk-neutral financiers with a single borrower with ability $\pi$.
} 


\subsubsection{Equilibrium}

Each entrepreneur with ability $\pi$ has rational expectations and chooses technology (safe or risky) to maximize her expected utility:

$$
\max _{T \in\{S, R\}} V^{T}(\pi)
$$

where

$$
\begin{aligned}
V^{S}(\pi) & =u\left(w^{S}\right) \\
V^{R}(\pi) & =\pi u\left(w^{H}(\pi)\right)+\left(1-\pi_{i}\right) u\left(w^{H}(\pi)\right) .
\end{aligned}
$$

In other words, every entrepreneur chooses technology, given her individual ability $\pi$ and the optimal financial contract $\left\{w^{H}(\pi), w^{L}(\pi)\right\}$ which solves $(P 1)$.

Definition Given the cost of misreporting, $p$, the equilibrium for this small open economy is defined as the set of technological choices and financial contracts $\left\{T(\pi), w^{H}(\pi)\right.$, $\left.w^{L}(\pi)\right\}_{\pi \in[0,1]}$, such that each agent with ability $\pi$ solves (P2), with payoffs solving (P1) subject to $\left(I C^{\prime}\right)$ and $(P C)$.

For simplicity, I assume that $\varphi A<B<A$ which implies that the risky technology is on average more productive than the safe one for some entrepreneurs.

\subsection{Solution}

To solve for the optimal technological choice $(P 2)$, entrepreneurs need to know the payoffs from the risky project, determined by the optimal financial contract $\left\{w^{H}(\pi), w^{L}(\pi)\right\}_{\pi \in[0,1]}$. Therefore, I proceed backwards and start by solving problem (P1) subject to (IC') and (PC). I first obtain the optimal contract under efficient markets (with no information asymmetry) and then compute the optimal payoffs in the presence of asymmetric information for a given level of investor protection. Next, I characterize technological choice $\{T(\pi)\}_{\pi \in[0,1]}$, given the optimal payoffs. Finally, I show how the equilibrium varies with the degree of investor protection.

\subsubsection{Optimal financial contract: efficient markets}

If investor could perfectly observe the cash flow of a firm, misreporting would be impossible, and hence the optimal financial contract would simply maximize the expected utility of a risk-averse borrower with success probability $\pi$ (P1) subject to the participation constraint of a perfectly diversified lender (PC). Thus, investors would provide entrepreneurs 
with full insurance in exchange for an expected gross return equal to the safe rate, as analytically shown in the first order conditions:

$$
\begin{aligned}
u^{\prime}\left(w^{H}(\pi)\right) & =u^{\prime}\left(w^{L}(\pi)\right)=u^{\prime}\left(w^{F B}(\pi)\right) \\
w^{F B}(\pi) & =\pi A+(1-\pi) \varphi A-1,
\end{aligned}
$$

where $u^{\prime}$ is the first derivative of $u$ and $w^{F B}(\pi)$ denotes the efficient, first-best, payoff of a risky entrepreneur with ability $\pi$, which is equal to her expected cash flow, increasing in ability, minus the risk-free interest rate repayment.

\subsubsection{Optimal financial contract: Asymmetric information}

If the cash flow cannot be observed by outsiders, entrepreneurs may have an incentive to misreport, and hence the optimal financial contract must also satisfy the incentive compatibility constraint (IC'). The first-best contract solves (P1) subject to (IC') and (PC) only if investor protection drives the gain from misreporting down to zero, which happens only for $p=1$. This means that when investor protection is perfect $(p=1)$, outside financiers can behave as if they were perfectly informed, and thus fully insure entrepreneurs without inducing them to misreport.

If investor protection is not perfect $(0 \leq p<1)$, first-best state-invariant earnings are not incentive compatible since $w^{F B}(\pi)<w^{F B}(\pi)+(1-p)(1-\varphi) A$ and entrepreneurs in the good state would be tempted to misreport their cash flow realization. Due to risk aversion, agents want to minimize the difference between the marginal utilities in the two states, $u^{\prime}\left(w^{H}(\pi)\right)-u^{\prime}\left(w^{L}(\pi)\right)$. The combination of $w^{H}(\pi)$ and $w^{L}(\pi)$ that achieves this goal and complies with incentive compatibility is the one satisfying $\left(I C^{\prime}\right)$ with equality. Investors' participation constraint $(P C)$ needs also hold with equality, so that the optimal financial contract satisfies the following first order conditions:

$$
\begin{aligned}
w^{H}(\pi) & =w^{L}(\pi)+(1-p)(1-\varphi) A, \\
w^{L}(\pi) & =\varphi A-1+\pi p(1-\varphi) A, \\
u^{\prime}\left(w^{H}(\pi)\right) & <u^{\prime}\left(w^{L}(\pi)\right) .
\end{aligned}
$$

\subsubsection{Technological choice}

Entrepreneurs with ability $\pi$ will choose the risky technology if it gives at least the same expected utility as the safe project:

$$
T(\pi)=R \Longleftrightarrow V^{R}(\pi) \geq V^{S}
$$


Since the state-contingent payoffs of a risky entrepreneur, $w^{H}(\pi)$ and $w^{L}(\pi)$ in equations (1) and (2), increase with ability $(\pi)$, while the difference between them is independent of it, her expected utility, $V^{R}$, is also increasing with ability. Expected utility of a safe entrepreneur, instead, is constant and does not depend on ability. This implies that the solution to the technological choice problem (P2) features a threshold ability level $\pi^{*}$ such that the agents with ability higher than $\pi^{*}$ choose the risky technology while those with lower ability choose the safe project. This property is formalized in Lemma 1.

Lemma 1 There exists a unique $\pi^{*}$ such that $\forall \pi \geq \pi^{*}, \pi u\left(w^{H}(\pi)\right)+(1-\pi) u\left(w^{L}(\pi)\right) \geq$ $u\left(w^{S}\right)$ ), and $\left\{w^{H}(\pi), w^{L}(\pi)\right\}$ is the solution to $(P 1)$ subject to $\left(I C^{\prime}\right)$ and $(P C)$. Proof. See the Appendix.

Note that, due to risk aversion, the expected payoff of risky entrepreneurs with ability equal to the threshold, $\pi^{*} w^{H}\left(\pi^{*}\right)+\left(1-\pi^{*}\right) w^{L}\left(\pi^{*}\right)$, must be higher than the safe earnings, $w^{S}$.

\subsubsection{Investor protection and the equilibrium}

To study how investor protection affects the equilibrium of the model, I first focus on the optimal financial contract and then on technological choice. The optimal payoffs of risky entrepreneurs can be conveniently re-written as

$$
\begin{aligned}
w^{H}(\pi) & =w^{F B}(\pi)+(1-\pi)(1-p)(1-\varphi) A \\
w^{L}(\pi) & =w^{F B}(\pi)-\pi(1-p)(1-\varphi) A .
\end{aligned}
$$

The first component, $w^{F B}(\pi)$, represents the payoff of a risky entrepreneur with ability $\pi$ under perfect investor protection $(p=1)$. The second term is the adjustment that investors have to set to induce truth-telling, which is state contingent and varies with ability and investor protection. This term is positive in the good and negative in the bad state to offset the temptation of an entrepreneur to misreport cash flow. It is decreasing in $p$ because when the unit cost of hiding cash flow is high, the temptation to misreport is low and hence a smaller deviation from the first best is enough to achieve truth-telling. It follows that also the wedge between state-contingent earnings, $w^{H}(\pi)-w^{L}(\pi)$, measuring the price that entrepreneurs have to pay for the temptation to misreport, is decreasing in investor protection. Moreover, since more skilled entrepreneurs are more likely to be in the good state, and hence to be tempted to hide cash flow, higher ability implies lower payoffs in both states relative to the efficient case, as long as investor protection is not perfect. Overall, both $w^{H}(\pi)$ and $w^{L}(\pi)$ are increasing in entrepreneurial ability, 
as clearly suggested by equations (1) and (2). Finally, notice that for $p=0$, implying a constant repayment equal to the risk-free rate, the entire risk is borne by the entrepreneur.

Expected earnings of a risky entrepreneur with ability $\pi$,

$$
E[w \mid \pi]=[\pi(1-\varphi)+\varphi] A-1
$$

are equal to the first best payoff, $w^{F B}(\pi)$, and do not vary with investor protection. Her expected utility, due to risk aversion, falls when the difference between state-contingent earnings grows. Therefore, a rise in $p$, by reducing the gap between $w^{H}(\pi)$ and $w^{L}(\pi)$, increases the expected utility of risky entrepreneurs, $V^{R}$.

Since equilibrium earnings are functions of investor protection and the technological parameters, also the threshold ability $\pi^{*}$ varies with $p, A, \varphi$ and $B$, as formalized in Lemma 2.

Lemma 2 The threshold ability $\pi^{*}$ is a decreasing function of investor protection $(p)$ and technological level of the risky sector $(A)$; it increases with the riskiness of the risky technology (inverse of $\varphi$ ) and the productivity of the safe one $(B)$ :

$$
\frac{\partial \pi^{*}}{\partial p}<0 ; \frac{\partial \pi^{*}}{\partial A}<0 ; \frac{\partial \pi^{*}}{\partial \varphi}<0 ; \frac{\partial \pi^{*}}{\partial B}>0
$$

Proof. See the Appendix.

Intuitively, stronger investor protection allows entrepreneurs to better share risks with investors, thereby raising the expected utility drawn from the risky project. Since payoffs and hence $V^{R}$ are increasing in ability, a rise in $p$ makes the risky technology preferable to the most able among safe entrepreneurs, i.e. reduces threshold ability $\pi^{*}$. A higher $A$ implies that productivity of the risky project increases, and more so in the good state. As a consequence, payoffs rise but also the wedge between them. Since the overall effect on expected utility is positive, a more productive technology reduces the threshold ability for risky entrepreneurship. The parameter $\varphi$ captures the riskiness of the risky technology (maximum risk for $\varphi=0$, no risk for $\varphi=1$ ), and also affects its expected productivity. If it grows, it makes the risky option preferable to the most able among safe entrepreneurs because it reduces the volatility of state-contingent earnings and increases their expected value, thereby raising expected utility. Trivially, higher productivity in the safe industry, $B$, makes it more attractive, thereby inducing the least able among risky entrepreneurs to adopt the safe technology, which rises the threshold $\pi^{*}$.

The threshold also depends on risk aversion, since the curvature of the utility function affects expected utility for given probability of success ( $\pi$, i.e., ability). For instance, with 
logaritmic utility, the risky technology is not run in equilibrium $\left(\pi^{*}=1\right)$ as long as the earnings of the most able in the bad state are non positive, i.e., for $p \leq(1-\varphi A) /[(1-$ $\varphi) A]$, which is positive for $\varphi A<1$. Alternatively, when risk aversion is sufficiently low, there may be entrepreneurs choosing the risky project even in the absence of investor protection $\left(\pi^{*}(0)=\pi_{\max }^{*}<1\right)$.

In the case of perfect investor protection $(p=1)$, the risky technology gives higher expected utility than the safe one whenever its expected productivity is higher: $[\pi+(1-\pi) \varphi] A$ $\geq B$. Therefore, it is easy to derive a closed form solution for the threshold ability,

$$
\pi_{p=1}^{*}=\frac{B-\varphi A}{(1-\varphi) A}
$$

and verify that it lies in the support of $\pi$ under the hypothesis that $\varphi A<B<A$.

In the general case of imperfect investor protection $(0 \leq p<1)$, the expression for the threshold is more involved. However, payoffs are easily derived as:

$$
w(\pi)=\left\{\begin{array}{lll}
w^{S} & \text { with probability } 1 & \text { for } \pi<\pi^{*} \\
w^{H}(\pi) & \text { with probability } \pi & \text { for } \pi \geq \pi^{*} \\
w^{L}(\pi) & \text { with probability } 1-\pi & \text { for } \pi \geq \pi^{*}
\end{array}\right.
$$

where $w^{H}(\pi)$ and $w^{L}(\pi)$ are given by (1) and (2). Henceforth, I denote the threshold abilities associated with $p=1$ and $0 \leq p<1$ by $\pi_{p=1}^{*}$ and $\pi_{p<1}^{*}$, respectively. For $p=1$, perfect risk sharing is achieved through the optimal financial contract, so that the whole payoff schedule $w(\pi)$ is state independent and exhibits no jump at the threshold ability. When $0 \leq p<1$, the earnings of risky entrepreneurs are state contingent and hence, due to risk aversion, at $\pi=\pi_{p<1}^{*}$ their expected value needs to be higher than the safe wage.

Figure 1 illustrates the equilibrium ability-earnings profiles. If there is perfect investor protection, $p=1$, income of entrepreneurs is described by the solid line. It is flat and equal to $w^{S}$ for the less able, who run the safe project, and proportional to ability for the more talented ones, who run the risky project. Due to perfect risk sharing, earnings are constant across states. If investor protection drops to $0 \leq p<1$ (dashed line), financing a risky firm becomes more costly, thereby inducing the least able among entrepreneurs to shift to the safe technology. Graphically, (1) the mass of risky firms shrinks, i.e., the flat segment of the earnings profile becomes longer. I define this as the "risk taking" effect. (2) Earnings become state contingent, and the wedge between $w_{p<1}^{H}$ and $w_{p<1}^{L}$ widens as $p$ falls due to worse risk sharing. I call this the "risk sharing" effect. The fact that imperfect insurance reduces expected utility of risky entrepreneurs is captured by the jump in expected earnings at the threshold $\pi_{p<1}^{*}$. 


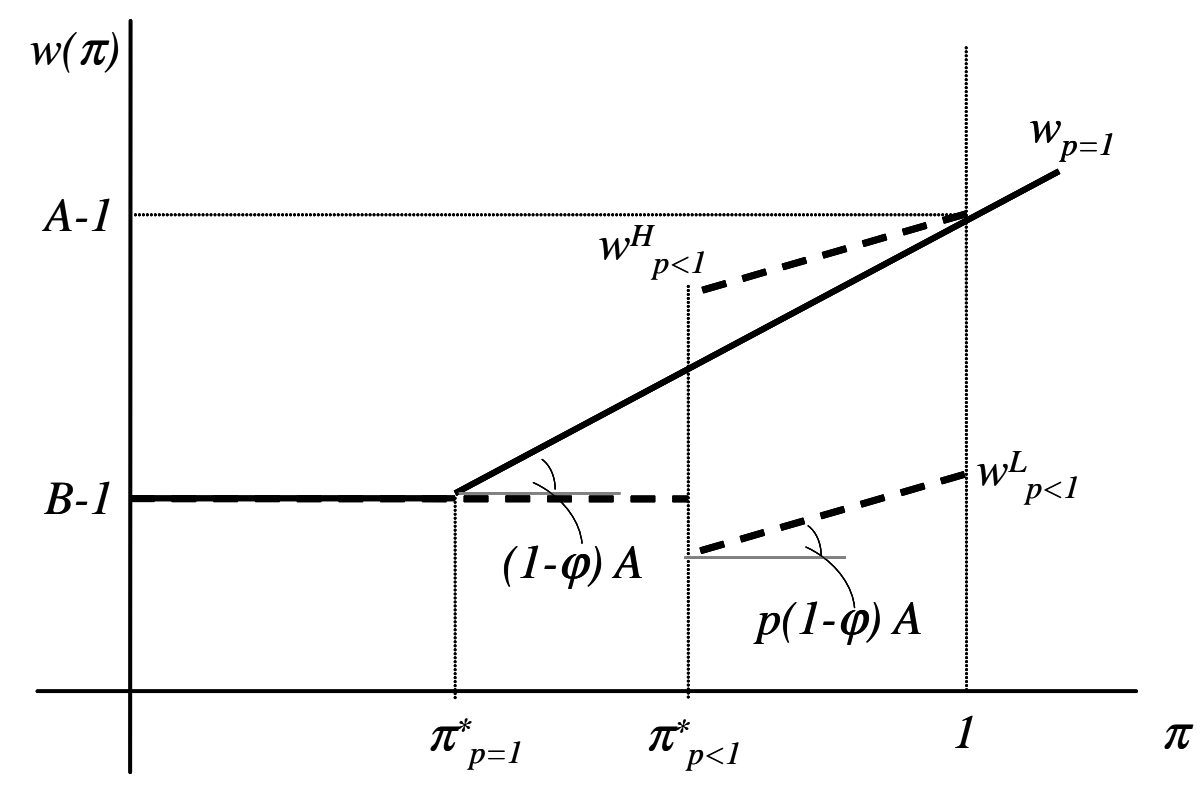

Figure 1: Ability and Earnings in Equilibrium.

The mass of entrepreneurs choosing the risky project represents the degree of risk taking in the economy and is analytically characterized as

$$
\rho \equiv 1-G\left(\pi^{*}\right)
$$

which is proven to be decreasing in the threshold ability and increasing in investor protection, and to vary with technological parameters.

Corollary 1 Risk taking $(\rho)$ is decreasing in the threshold ability $\left(\pi^{*}\right)$, the riskiness of the risky technology (inverse of $\varphi$ ) and the productivity of the safe one $(B)$ :

$$
\frac{\partial \rho}{\partial \pi^{*}} \leq 0, \frac{\partial \rho}{\partial \varphi} \geq 0, \frac{\partial \rho}{\partial B} \leq 0
$$

it is increasing in investor protection (p) and technological level of the risky sector $(A)$ :

$$
\frac{\partial \rho}{\partial p} \geq 0, \frac{\partial \rho}{\partial A} \geq 0
$$

Proof. See the Appendix. 


\section{Evaluating income Distribution}

In this section, I study how investor protection affects income inequality. I first take as a simple measure of income inequality the ratio between the highest and the lowest realizations of earnings, and characterize analytically how it varies with investor protection due to the "risk taking" and "risk sharing" effects. Next, I consider measures of inequality accounting for the entire distribution of income such as the variance and the Gini coefficient, and show analytically and by means of numerical solution how these respond to changes in investor protection.

I denote with $\omega$ the ratio between top and bottom earnings:

$$
\omega=\frac{w^{\max }}{w^{\min }} .
$$

Trivially, if no risky project is run, all agents earn $w^{S}$ with certainty and there is no inequality, so that $\omega=1$. In the general case, when both technologies are used, $w^{\text {min }}$ is earned by the least able among risky entrepreneurs, as $w^{L}(\pi)$ is lower than or equal to $w^{H}(\pi)$ for any $\pi$ and increasing in ability. Since these agents draw the same expected utility from both projects, $\pi^{*} u\left(w^{H}\left(\pi^{*}\right)\right)+\left(1-\pi^{*}\right) u\left(w^{L}\left(\pi^{*}\right)\right)=u\left(w^{S}\right)$, it must be that $u\left(w^{L}\left(\pi^{*}\right)\right) \leq u\left(w^{S}\right)$, which implies, by monotonicity of the utility function, that $w^{L}\left(\pi^{*}\right) \leq w^{S}$. The highest realization of earnings belongs to the most able entrepreneurs, $w^{\max }=w^{H}(1)=A-1$. Hence, the general expression for $\omega$ is

$$
\omega=\frac{A-1}{\varphi A-1+\pi^{*} p(1-\varphi) A} .
$$

For given threshold ability, an increase in investor protection improves risk sharing thereby raising the earnings of unlucky entrepreneurs and reducing the ratio of top to bottom earnings. For given investor protection, an increase in the threshold ability (e.g., due to higher risk aversion), corresponding to a drop in risk taking, implies that the least able among risky entrepreneurs have higher ability and hence face higher earnings (recall that both $w^{H}$ and $w^{L}$ are increasing in $\pi$ ). This means that inequality falls with threshold ability and increases with risk taking, as formalized in Proposition 1 and Corollary 2.

Proposition 1 For a given threshold ability of risky entrepreneurs, $\pi^{*}$, better investor protection reduces the ratio of top to bottom earnings:

$$
\left.\frac{\partial \omega}{\partial p}\right|_{\pi^{*}} \leq 0
$$

for a given level of investor protection, $p$, an increase in the threshold ability of risky 
entrepreneurs reduces the ratio of top to bottom earnings:

$$
\left.\frac{\partial \omega}{\partial \pi^{*}}\right|_{p} \leq 0
$$

Proof. See the Appendix.

Corollary 2 For a given degree of risk taking, $\rho$, better investor protection reduces the ratio of top to bottom earnings:

$$
\left.\frac{\partial \omega}{\partial p}\right|_{\rho} \leq 0 ;
$$

for given ability distribution, $G$, and level of investor protection, $p$, an increase in the degree of risk taking increases the ratio of top to bottom earnings:

$$
\left.\frac{\partial \omega}{\partial \rho}\right|_{p} \geq 0 .
$$

Proof. See the Appendix.

An alternative measure of inequality that takes into account the entire income distribution is the variance of the earnings realizations:

$$
\begin{aligned}
\operatorname{Var}(w)= & G\left(\pi^{*}\right)\left[w^{S}-\mathbb{E}[w]\right]^{2}+\int_{\pi^{*}}^{1} \pi\left(w^{H}(\pi)-\mathbb{E}[w]\right)^{2} g(\pi) d \pi \\
& +\int_{\pi^{*}}^{1}(1-\pi)\left(w^{L}(\pi)-\mathbb{E}_{[w]}\right)^{2} g(\pi) d \pi
\end{aligned}
$$

where

$$
\mathbb{E}[w]=G\left(\pi^{*}\right) w^{S}+\int_{\pi^{*}}^{1} \mathbb{E}[w \mid \pi] g(\pi) d \pi
$$

is the average income in the economy. Lemma 3 proves $\mathbb{E}[w]$ to be increasing in investor protection.

Lemma 3 Average entrepreneurial earnings, $\mathbb{E}[w]$, are increasing in investor protection, $p$.

$$
\frac{d \mathbb{E}[w]}{d p} \geq 0
$$

Proof. See the Appendix.

Intuitively, an increase in the cost of misreporting, $p$, gives risky entrepreneurs better insurance, thereby encouraging more agents to choose the risky technology (i.e., a drop in the threshold ability, $\pi^{*}$ ). Risk aversion requires that these marginal entrepreneurs, with mass $g\left(\pi^{*}\right)$, enjoy higher expected earnings when switching from the safe to the 
risky sector, and thus they contribute to increase average income. This implies that also aggregate production and welfare increase with investor protection, and this effect is driven by "risk taking".

Equation (3) for the variance of earnings suggests that better investor protection affects inequality both through the "risk sharing" and the "risk taking" effect: by the former, it closes the wedge between state-contingent earnings of entrepreneurs, thereby reducing income differentials among agents with the same ability, $\pi \geq \pi^{*}$, and hence overall inequality. Analytically, holding $\pi^{*}$ constant, a rise in $p$ reduces the terms under integration in (3). This effect is more pronounced the larger the mass of risky entrepreneurs, $\rho=1$ $-G\left(\pi^{*}\right)$ (i.e., the lower the threshold ability), as formalized and proved in Proposition 2 and Corollary 3. For given investor protection, however, a drop in the threshold ability $\pi^{*}$ implies that a mass $g\left(\pi^{*}\right)$ of agents switches to state-contingent earnings, which is likely to translate into higher inequality.

Proposition 2 For a given threshold ability of risky entrepreneurs, $\pi^{*}$, better investor protection reduces the variance of the earnings distribution:

$$
\left.\frac{\partial V a r}{\partial p}\right|_{\pi^{*}} \leq 0
$$

better investor protection reduces inequality more where the threshold is lower:

$$
\left.\frac{\partial V a r}{\partial p}\right|_{\pi^{*}=\pi_{1}^{*}}<\left.\frac{\partial V a r}{\partial p}\right|_{\pi^{*}=\pi_{2}^{*}}, \text { for any } \pi_{1}^{*}<\pi_{2}^{*} \text {. }
$$

Proof. See the Appendix.

Corollary 3 For a given degree of risk taking, $\rho$, better investor protection reduces the variance of the earnings distribution:

$$
\left.\frac{\partial V a r}{\partial p}\right|_{\rho} \leq 0
$$

for given ability distribution, $G$, better investor protection reduces inequality more where there is more risk taking, $\rho=1-G\left(\pi^{*}\right)$ :

$$
\left.\frac{\partial V a r}{\partial p}\right|_{\rho=\rho_{1}}<\left.\frac{\partial V a r}{\partial p}\right|_{\rho=\rho_{2}}, \text { for any } \rho_{1}>\rho_{2} .
$$

Proof. See the Appendix.

The overall impact of investor protection on income inequality depends on the strength of the "risk sharing" and "risk taking" effects. In particular, when the cost of misreporting, 
and hence the size of the risky sector, is close to its maximum, the "risk taking" effect is weak, since the marginal entrepreneurs do not add much to the existing mass of risky firms. The "risk sharing" effect is instead very strong since it applies to nearly all potential risky entrepreneurs, and hence an increase in $p$ reduces inequality. When investor protection is very low, there is a small mass of risky firms in the economy and hence the "risk taking" effect is strong at the margin, while the "risk sharing" effect is weak since it applies to few entrepreneurs. It follows that an improvement in investor protection when this is already high is likely to reduce inequality, while it increases it when $p$ is low. The smaller the share of risky entrepreneurs in presence of low investor protection - e.g., due to high risk aversion, technological risk (low $\varphi$ ) or right skewness of the ability distribution - the wider the range of $p$ for which income inequality is increasing in investor protection.

Although intuitive, the result that inequality may be an inverse- $\mathrm{U}$ function of investor protection is awkward to prove analytically, since the sign of the total differential of inequality with respect to investor protection depends also on the utility function and the distribution of ability. Solving the model numerically allows me to easily compute alternative measures of inequality, study how they vary with the parameter $p$, and evaluate how the "risk sharing" and the "risk taking" effects shape this relationship. To this end, I assume that the utility is logaritmic and the ability distribution is lognormal with mean and variance taken from the actual distribution of years of schooling for the US, and set the technological parameters $(A, B$ and $\varphi)$ so as to satisfy the model restrictions. ${ }^{10}$ Based on the earnings distributions derived numerically, I compute two indicators of inequality: the variance and the Gini coefficient. Figure 2 plots the two measures of inequality against investor protection under different values of the parameter $\varphi$, which captures the riskiness of technology. I solve the model under different riskiness parameters to generate variation in risk taking independent of investor protection, and hence to be able to isolate the "risk taking" effect. ${ }^{11}$ Recall that, as predicted by Lemma 2 and Corollary 1, risk taking is increasing in investor protection $(p)$ and decreasing in technological riskiness. Note also that nearly all entrepreneurs in the simulation for low risk choose the risky technology independently of investor protection, so that the "risk taking" effect is virtually absent in this case. Figure 2 shows that both the variance and the Gini coefficient of the earnings distribution may be non-monotonic in investor protection. In particular, inequality is increasing in investor protection when $p$ is sufficiently low, and becomes decreasing when there is enough risk taking. The "risk sharing" effect is effectively illustrated by

\footnotetext{
${ }^{10}$ This numerical solution has no quantitative aim. All details are given in the Appendix.

${ }^{11}$ Alternatively, I could assume a CRRA utility function and let the risk aversion parameter vary. The results, available upon request, are analogous.
} 
the downward-sloping lines for the low-risk technology, which exhibit a sharp decline in inequality associated to an increase in $p$ when nearly all firms adopt the risky technology independently of investor protection. The "risk taking" effect is instead captured by the initial upward-sloping part of the lines for the middle and high risk cases, and by the fact that, for any value of $p$, inequality is higher when the riskiness is lower and hence risk taking is larger. The analytical results of Proposition 2 and Corollary 3 (inequality decreases faster with investor protection when risk taking is larger) can be found in Figure 2 by comparing the slope of the declining parts of the lines for different riskiness at any level of investor protection: inequality falls more with $p$, the more risk is taken in the economy.
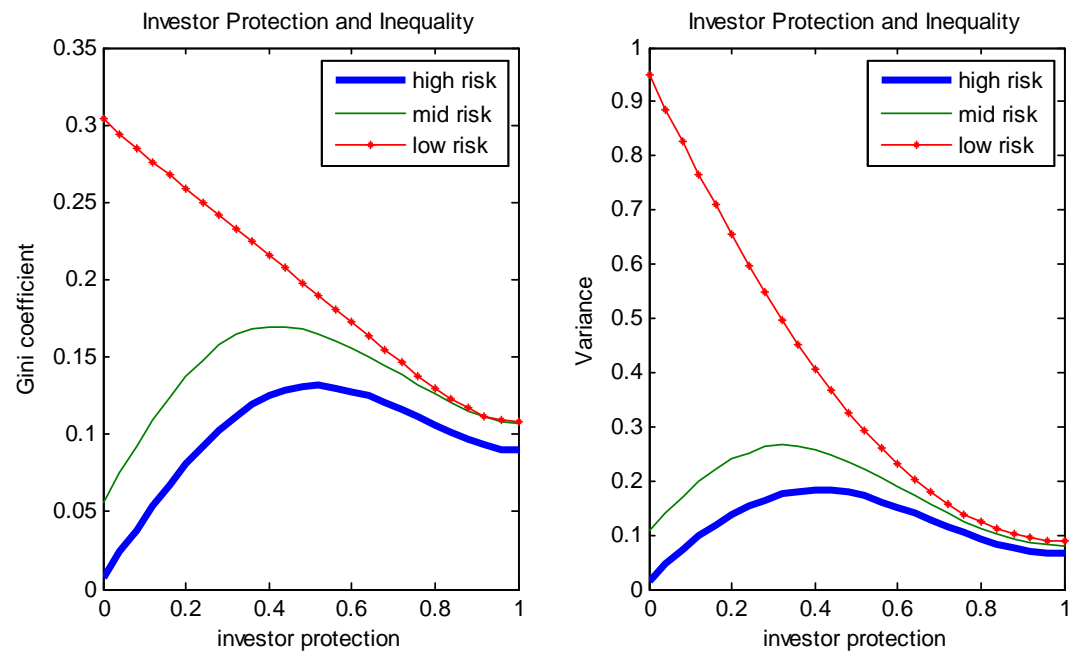

Figure 2: Investor Protection and Income Inequality.

\section{Empirical Analysis}

In this section, I evaluate empirically the main theoretical predictions derived in section 3. First, I assess the overall effect of investor protection on income inequality. Next, as a preliminary step to study the mechanism behind this relationship, I address the effect of investor protection on risk taking predicted by Lemma 2 and Corollary 1. Finally, I study the different impact of investor protection on inequality through risk taking and risk sharing, as predicted by Propositions 1 and 2, and Corollary 2 and 3.

Since investor protection is generally determined by law, it is not expected to exhibit large variation across geographical areas or sectors within a country. Hence, cross-country data, possibly with time variation, seem appropriate to evaluate empirically the predictions 
of the model.

\subsection{DATA}

The first empirical task is to measure the three main variables of interest: inequality, investor protection and risk taking. I proxy the dependent variable, inequality, with the Gini coefficient of the income distribution which is a widely used measure and is available for a relatively large sample of countries and years. I take the data from Dollar and Kraay's (2002) database that relies on four sources: the UN-WIDER World Income Inequality Database, the "high quality" sample from Deininger and Squire (1996), Chen and Ravallion (2001), and Lundberg and Squire (2000). ${ }^{12}$ The Gini coefficients I use are computed over the entire population, while it may be argued that the theory proposed in the paper refers to entrepreneurs, who are usually in the top percentiles of the income distribution. This may weaken the empirical evidence in favor of the model, rather than bias it upwards, if investor protection does not affect the income of the poor through other channels, or does it reducing inequality. On the other hand, there is evidence from several countries that a large fraction of the variation in income inequality over the last two decades is explained by changes at the top of the distribution (see, among others, Atkinson et al., 2009 and Heathcote et al., 2010). This suggests that the effects of investor protection on inequality at the top of the distribution are likely to prevail even on aggregate data for the entire population. Moreover, due to profit sharing, also employees normally earn higher wages and are subject to higher employment risk when working in more productive and riskier firms. ${ }^{13}$ Hence the results obtained for entrepreneurs can be expected to trickle down to all workers. Alternatively, the model could be reinterpreted in light of an occupational choice whereby workers face no risk and hence are akin to agents running safe projects, while entrepreneurs do. Inequality in this case would increase with the diffusion of entrepreneurship and decrease with the degree of risk sharing.

I take as a measure of investor protection the index of shareholder protection compiled by La Porta et al. (2006), that takes values between 0 (no protection) and 10 (maximum protection). For robustness, I also consider the index of anti directors' self-dealing mea-

\footnotetext{
${ }^{12}$ The original sample consists of 953 observations, which reduce to 418 separated by at least five years, on 137 countries over the period 1950-1999. Countries differ with respect to the survey coverage (national vs subnational), the welfare measure (income vs expenditure), the measure of income (net vs gross) and the unit of observation (households vs individuals). For better comparability, data from Deininger and Squire are usually adjusted by adding 6.6 to the Gini coefficients based on expenditure. Here, the adjustment was made in a slightly more complicated way to account for the variety of sources; see Dollar and Kraay (2002) for details.

${ }^{13}$ Evidence that more productive firms pay higher wages is provided, among others, by Oi and Idson (1999).
} 
sures compiled by La Porta et al. (2006) and taking values between 0 (no protection) and 6 (maximum protection). Both indexes are available for 49 developed and developing countries and have no time variation, which is their main limitation.

Risk taking in the model stems directly from the threshold ability of the marginal risky entrepreneur, and is captured by the mass of risky projects undertaken in the economy. Its ideal empirical counterpart is the possibility for firms to undertake risky projects. It was shown by the corporate finance literature that a firm that relies more on external equity relative to debt finance is in a better position to embark in risky projects such as innovation (see for instance Brown et al., 2009). Moreover, recent empirical evidence by Thesmar and Thoenig (2009) shows that firms take more risk and have more volatile performance, the higher the fraction of external equity in their financial structure. Therefore, I proxy entrepreneurial risk taking at the aggregate level with the ratio between stock market capitalization and credit to the private sector. Data for both series, expressed as a share of GDP are taken from the 2009 update of the database by Beck et al. (2000) on Financial Development and Structure.

When combining the three data sources for the main dependent and explanatory variables, I am left with an unbalanced panel of 45 countries observed over the period 19762000. ${ }^{14}$ Table A reports descriptive statistics for the relevant variables.

\subsection{Cross-Sectional Estimates}

First, I focus on the cross-section of 45 countries and estimate with Ordinary Least Squares the following equation for the overall effect of investor protection on inequality, as shown in Figure 2:

$$
\text { Gini }_{i}=\alpha_{0}+\alpha_{1} I P_{i}+\alpha_{2} I P_{i} * I P_{-} h i g h_{i}+\alpha_{3} X_{i}+\epsilon_{i}
$$

The variable Gini is the measure of income inequality, $i$ is the country index, IP is the indicator of investor protection, $I P_{-}$high is a dummy taking value 1 if investor protection is above the sample median (i.e., 4.6) and zero otherwise, $X$ is a vector of control variables, and $\epsilon$ is the error term. Following the empirical literature on income inequality, I include in $X$ the $\log$ of the real per capita GDP and its square, to account for the Kuznets' hypothesis, the share of population above 25 years that completed secondary education (from Barro and Lee, 2001) to control for education, government expenditure as a ratio

\footnotetext{
${ }^{14}$ The countries in the sample are: Australia, Austria, Belgium, Brazil, Canada, Chile, Colombia, Denmark, Ecuador, Egypt, Finland, France, Germany, Greece, Hong Kong, India, Indonesia, Ireland, Israel, Italy, Japan, Jordan, Kenya, Korea, Malaysia, Mexico, Netherlands, New Zealand, Norway, Pakistan, Peru, Philippines, Portugal, Singapore, South Africa, Spain, Sri Lanka, Sweden, Switzerland, Thailand, Turkey, United Kingdom, United States, Uruguay, Venezuela.
} 
of GDP to account for the degree of redistribution, and total trade (Export+Import) as a ratio of GDP (from the Penn World Tables 6.3). The empirical evidence is in line with the predictions of the model if the estimates for $\alpha_{1}$ and $\alpha_{2}$ are positive and negative respectively, meaning that inequality first increases and then falls as investor protection grows. All variables are expressed in period average for the period 1980-2000.

Table 1 reports the estimated coefficients. In column 1, I only control for investor protection and education and obtain a non significant $\alpha_{1}$, suggesting that there is no clear correlation. As soon as I allow for non-linearity in investor protection, I obtain significant coefficients with the expected sign: positive $\alpha_{1}$ and negative $\alpha_{2}$. These results hold if I control for real GDP per capita and its square, government expenditure and trade over GDP, in columns 3 and 4 . In columns 5 and 6 , I replace the indicator of investor protection $I P$ with the de jure index of anti directors' self dealing measures and obtain analogous, albeit weaker, results. To correct for a possible simultaneity, in columns 7-9, I take the last available observation of the Gini coefficient for each country and regress it on the same variables as in columns 1-3. The estimates are qualitatively and quantitatively very close to the ones for period averages. These results suggest that the relationship between investor protection and income inequality is non-monotonic in the way predicted by the model. Further analysis is needed to assess if the mechanism generating this evidence is the one proposed in sections 2 and 3 .

As a preliminary step to evaluate the empirical relevance of the mechanism proposed in the model, I test whether investor protection induces entrepreneurial risk taking, which is the force behind the positive $\alpha_{1}$ coefficient. To this end, I estimate the following equation:

$$
R T_{i}=a_{0}+a_{1} I P_{i}+a_{2} Z_{i}+e_{i}
$$

where $R T$ is the proxy for risk taking, i.e., the ratio of stock market capitalization over total credit to the private sector, $Z$ is a vector of control variables, and $e$ is the error term. Data are averaged over the period 1980-2000. Following La Porta et al. (2006), I include in $Z$ the real per capita GDP and an index of efficiency of the judiciary system (eff_jud from La Porta et al., 2006). I first estimate (4) with OLS and then, to control for possible endogeneity of investor protection with respect to relative stock market size, with Two-Stages Least Squares instrumenting investor protection with dummies for UK, French and German legal origins. The results, reported in Table 2, exhibit positive and significant estimates of $a_{1}$ both with OLS and 2SLS Instrumental Variables. This is in line both with Corollary 1 and with the evidence in La Porta et al. (2006), and suggests that indeed entrepreneurial risk taking increases with investor protection. These results are robust to the use of an alternative measure of investor protection (antidir). 
Testing the main theoretical result that investor protection reduces inequality for a given degree of risk taking, as stated in the first part of Corollary 2 and in Corollary 3, while risk taking tends to increase it for a given level of $I P$, as proven in the second part of Corollary 2 and shown in Figure 2, requires regressing the Gini index on IP and the measure of risk taking. I do this using panel data, which allow me to exploit the additional information conveyed by the time variation in all variables except the measure of investor protection.

\subsection{Panel Estimates}

I exploit the time variation in the data for inequality and risk taking to test the main prediction of the model by estimating with least squares the following equation:

$$
\operatorname{Gini}_{i t}=\beta_{0}+\beta_{1} I P_{i}+\beta_{2} R T_{i t}+\beta_{3} X_{i t}+\nu_{i t},
$$

where time subscripts refer to non-overlapping 5-year periods between 1976 and 2000, all regressors are the same as described above, and $\nu_{i t}$ is the error term. I first estimate this equation with random effects, clustering the standard errors by country, which allows me to characterize the link between investor protection and inequality across countries over time. A negative estimate for $\beta_{1}$ and a positive one for $\beta_{2}$ would lend support to the model prediction that investor protection reduces inequality for a given degree of risk taking, while risk taking tends to increase it for a given level of IP. Note that four countries are dropped from the sample since there are no observations for all variables corresponding to the same five-year periods. ${ }^{15}$

The results are reported in Table 3 . Columns 1 and 2 replicate the estimates of Table 1 and confirm that inequality is non monotonic in investor protection. Column 3 suggests that indeed $\beta_{1}$ is negative, though not significant, and $\beta_{2}$ positive. Column 4 , accounting both for the non-linearity in $I P$ and $R T$, confirms that risk taking raises inequality $\left(\beta_{2}\right.$ positive), while risk sharing reduces it when investor protection is sufficiently high (IP positive, $I P * I P \_$high negative). In columns 5-7, I study the combined effect of risk sharing and risk taking by adding to equation (5) the interaction terms $R T * I P$ and, alternatively, $R T * I P \_h i g h$. In both cases, the table reports a positive $\beta_{2}$ and a negative coefficient for the interaction, meaning that investor protection may reduce inequality when there is enough risk taking, and that $R T$ has weaker effect on inequality when $I P$ is high, as predicted by Corollaries 2 and 3 and shown in Figure 2 For robustness check, in the regressions of Panel B, I replace the investor protection index with the anti directors'

\footnotetext{
${ }^{15}$ These countries are Hong Kong, Ireland, Switzerland and Uruguay.
} 
self dealing indicator. The results confirm the evidence in Panel A: improving the degree of protection of outside shareholders increases inequality by promoting risk taking, but less so in countries that already have a high degree of investor protection. On the other hand, more risk taking, independently of whether it is caused by investor protection, increases inequality.

When I estimate equation (5) with fixed effects, the variable IP is dropped from the estimation, since it has no time variation and cannot be distinguished from the countryspecific component, so that the "risk taking" and "risk sharing" channels can no longer be evaluated separately as before. Hence, I take a different approach and estimate

$$
\text { Gini }_{i t}=\gamma_{0}+\gamma_{1} I P_{i} * R T_{i t}+\gamma_{2} R T_{i t}+\gamma_{3} X_{i t}+\eta_{i}+\varepsilon_{i t}
$$

where $\eta_{i}$ is the country fixed effect, $R T$ alone accounts for "risk taking", and the interaction term captures the differential effect it has in countries with better investor protection. A negative $\gamma_{1}$ and a positive $\gamma_{2}$ would lend support to the model prediction, since they would imply that risk taking, regardless of what generates it, increases income inequality, but less so where investor protection is high since it provides better risk sharing.

Table 4 reports the results obtained both with random and fixed effects. The estimates for $\gamma_{1}$ and $\gamma_{2}$ have the expected negative and positive signs throughout all specifications and lend support to the mechanism proposed in sections 2 and 3 . The results appear stronger when country fixed effects are accounted for and when the interaction is set between $R T$ and the dummy for high $I P$, suggesting that the risk-sharing effect becomes relevant for high enough degrees of investor protection.

For robustness check, in the regressions of Panel B, I replace the investor protection index with the anti directors' self dealing indicator. Also in this case, the results confirm the evidence in Panel A.

\section{Conclusions}

This paper provides theoretical and empirical support for a systematic relationship between investor protection and income inequality through financial risk sharing and entrepreneurial risk taking. While there are contributions addressing the effects of investor protection on financial structure, risk sharing and economic growth, no attention has been paid to the implications for income distribution. To fill this gap, I develop a simple static model with risk-averse agents, heterogeneous in their ability, that can produce using either a safe or a risky technology. I assume that entrepreneurs have to borrow funds in order to start their business, and that there are financial frictions, arising from the 
non-observability of a firm's cash-flow to investors.

In this framework, I study how investor protection, by alleviating frictions, affects optimal financial contracts, the technological choice of agents with different ability and the distribution of their earnings. Better investor protection affects income inequality in two opposite ways. By improving risk sharing between entrepreneurs and financiers, it reduces income volatility for a given mass of risky firms. On the other hand, by inducing more agents to choose the risky technology, it increases the dispersion of the earnings realizations. The first, "risk sharing", effect tends to reduce inequality, while "risk taking" raises it. The overall impact of investor protection on inequality is shown to be nonmonotonic. In particular, the "risk taking" effect dominates at low levels of investor protection, and is outweighed by "risk sharing" when investor protection is high. In the empirical section, I provide evidence from a panel of forty-five countries over the period 1976-2000 that is consistent with the main theoretical predictions.

The model is deliberately kept simple to emphasize the mechanism linking investor protection to income inequality. It follows that its implications for economic performance and welfare may appear simplistic: aggregate income increases with investor protection due to risk taking, and welfare increases due to higher output and better risk sharing. Yet, an interesting insight is that investor protection, through its positive effect on aggregate output and the non-monotonic impact on inequality, generates a Kuznets' curve. Contrary to existing models, this inverse-U shaped relationship between GDP and inequality is generated by the development of financial institutions, rather than by wealth accumulation. 


\section{REFERENCES}

[1] Acemoglu, Daron and Simon Johnson, 2005 "Unbundling institutions," Journal of Political Economy 113, 949-995.

[2] Acemoglu, Daron and Fabrizio Zilibotti, 1999 "Information Accumulation in Development," Journal of Economic Growth 4, 5-38.

[3] Aghion, Philippe and Patrick Bolton, 1997 "A theory of trickle-down growth and development," Review of Economic Studies 64, 151-172

[4] Aghion, Philippe, Peter Howitt and David Mayer-Foulkes, 2005 "The Effects of Financial Development on Convergence: Theory and Evidence," Quarterly Journal of Economics, 120.

[5] Atkinson, Anthony B., Thomas Piketty and Emmanuel Sáez, 2009 "Top Incomes in the Long Run of History," NBER Working Paper 15408.

[6] Banerjee, Abhijit and Andrew Newman, 1993 "Occupational Choice and the Process of Development," Journal of Political Economy 101, 274-298.

[7] Barro, Robert and Jong-Wha Lee, 2000 "International data on educational attainment: updates and implications," Harvard University Center for International Development Working Paper No 2.

[8] Beck, Thorsten, Asli Demirgüç-Kunt and Ross Levine, 2000 "A new database on financial development and structure," World Bank Economic Review, September 2000, 597-605.

[9] Beck, Thorsten, Asli Demirgüç-Kunt and Ross Levine, 2007 "Finance, Inequality and The Poor," Journal of Economic Growth 12(1), 27-49.

[10] Beck, Thorsten and Ross Levine, 2004 "Stock Markets, Banks, and Growth: Panel Evidence", Journal of Banking and Finance 28, 423-442.

[11] Benabou, Roland, 1996 "Inequality and Growth," NBER Macroeconomics Annual, B. Bernanke and J. Rotemberg, eds., 11-74.

[12] Brown, James R., Steven M. Fazzari and Bruce C. Petersen, 2009 "Financing Innovation and Growth: Cash Flow, External Equity, and the 1990s R\&D Boom," Journal of Finance 64(1), 151-185.

[13] Caselli, Francesco and Nicola Gennaioli, 2005 "Dynastic Management," manuscript. 
[14] Castro, Rui, Gian Luca Clementi and Glenn MacDonald, 2004 "Investor protection, Optimal Incentives and Economic Growth," Quarterly Journal of Economics, 119(3), 1131-1175.

[15] Clarke, George, Lixin Colin Xu and Heng-fu Zou, 2006 "Finance and Income Inequality: What Do The Data Tell Us?," Southern Economic Journal 72, 578-596

[16] Deininger, Klaus and Lyn Squire, 1996 "A new dataset measuring income inequality," World Bank Economic Review 10(3), 565-91.

[17] Dollar, David and Aart Kraay, 2002 "Growth is good for the poor," Journal of Economic Growth 7, 195-225.

[18] Fairlie, Robert and Alicia Robb, 2003 "Families, human capital, and small business: evidence from the Characteristics of Business Owners survey," Yale University Economic Growth Center Discussion Paper No. 871.

[19] Galor, Oded and Joseph Zeira, 1993 "Income Distribution and Macroeconomics," Review of Economics Studies 60, 35-52.

[20] Greenwood, Jeremy and Bojan Jovanovic, 1990 "Financial Development, Growth, and the Distribution of Income," Journal of Political Economy 98, 1076-1107.

[21] Heathcote, Jonathan, Fabrizio Perri and Gianluca Violante, 2010 "Unequal We Stand: An Empirical Analysis of Economic Inequality in the United States, 1967-2006," Review of Economic Dynamics 13(1), 15-51.

[22] Heston, Alan, Robert Summers and Bettina Aten, 2009 "Penn World Tables version 6.3," Center for International Comparisons at the University of Pennsylvania.

[23] Hurst, Erik and Annamaria Lusardi, 2004 "Liquidity constraints, household wealth, and entrepreneurship," Journal of Political Economy 112(2), 319-47

[24] La Porta, Rafael, Florencio F. Lopez-de-Silanes, Robert Vishny and Andrei Shleifer, 1997 "Legal Determinants of External Finance" Journal of Finance 52, 1131-1150.

[25] La Porta, Rafael, Florencio F. Lopez-de-Silanes, Robert Vishny and Andrei Shleifer, 1998 "Law and Finance," Journal of Political Economy 106, 1113-1155.

[26] La Porta, Rafael, Florencio F. Lopez-de-Silanes, Robert Vishny and Andrei Shleifer, 1999 "Corporate Ownership Around the World," Journal of Finance 54, 471-517. 
[27] La Porta, Rafael, Florencio F. Lopez-de-Silanes, Robert Vishny and Andrei Shleifer, 2000 "Investor Protection and Corporate Governance," Journal of Financial Economics 58, 3-27.

[28] La Porta, Rafael, Florencio F. Lopez-de-Silanes and Andrei Shleifer, 2006 "What Works in Securities Laws?," Journal of Finance .

[29] Lacker, Jeffrey and John Weinberg, 1989. "Optimal Contracts under Costly State Falsification," Journal of Political Economy 97(6), 1345-1363.

[30] Levine, Ross, 2005. "Finance and Growth: Theory and Evidence," in Philippe Aghion and Steven Durlauf, eds. Handbook of Economic Growth 1A, 865-934. The Netherlands: Elsevier Science.

[31] Lundberg, Mattias and Lyn Squire, 2000. "The simultaneous evolution of growth and inequality," World Bank, mimeo.

[32] Michelacci, Claudio and Fabiano Schivardi, 2010. "Does Idiosyncratic Business Risk Matter?," mimeo.

[33] Oi, Walter and Todd Idson, 1999. "Firm Size and Wages," in O. Ashenfelter \& D. Card, eds. Handbook of Labor Economics, edition 1, volume 3, chapter 33, pages 2165-2214 Elsevier

[34] Piketty, Thomas, 1997 "The dynamics of the wealth distribution and the interest rate with credit rationing," Review of Economic Studies 64, 173-189.

[35] Ravallion, Martin, 2001 "Measuring aggregate welfare in developing countries: how well do national accounts and surveys agree?," World Bank Policy Research Department Working Paper No. 2665.

[36] Ravallion, Martin and Shaohua Chen, 1997 "What Can New Survey Data Tell us about Recent Changes in Distribution and Poverty?," The World Bank Economic Review, 11, 357-382.

[37] Schiller, Bradley and Philip Crewson, 1997 "Entrepreneurial Origins: a Longitudinal Inquiry," Economic Enquiry 35, 523-532.

[38] Thesmar, David and Mathias Thoenig, 2009. "Contrasting Trends in Firm Volatility: Theory and Evidence," CEPR Discussion Paper 7135. 


\section{A Proofs}

\section{Lemma 1}

The assumptions that $A>B+1>\varphi A$ and $u^{\prime}>0$, imply that agents with $\pi=1$ always choose the risky technology since $V^{R}(1)=u\left(w^{H}(1)\right)=u(A-1)>u(B)=V^{S}$; while agents with $\pi=0$ always make the safe choice since $V^{R}(0)=u\left(w^{L}(0)\right)=u(\varphi A-$ $1)<V^{S}$. To prove that there exist a unique ability $\pi^{*} \in(0,1)$ such that $V^{R}(\pi)<(>)$ $V^{S}$ for all $\pi>(<) \pi^{*}$, I just need to show that $V^{R}$ is increasing in $\pi$. The derivative of $V^{R}$ w. r. t. $\pi$ under the optimal financial contract is

$$
\frac{\partial V^{R}}{\partial \pi}=u\left(w^{H}(\pi)\right)-u\left(w^{L}(\pi)\right)+p(1-\varphi) A\left[\pi u^{\prime}\left(w^{H}(\pi)\right)+(1-\pi) u^{\prime}\left(w^{L}(\pi)\right)\right]>0
$$

since $w^{H}(\pi)>w^{L}(\pi)$. Therefore, there exist a unique threshold ability $\pi^{*}$ such that $V^{R}\left(\pi^{*}\right)=V^{S}$ and $\forall \pi>\pi^{*}, \pi u\left(w^{H}(\pi)\right)+(1-\pi) u\left(w^{L}(\pi)\right)>u(B)$.

\section{Lemma 2}

To prove that the threshold ability is decreasing in investor protection, I characterize $\pi^{*}$ as implicit function of $p$,

$$
V^{R}\left(\pi^{*}, p\right)=V^{S}
$$

and obtain its derivative with respect to $p$ as

$$
\frac{\partial \pi^{*}}{\partial p}=-\frac{\partial V^{R}}{\partial p}\left(\frac{\partial V^{R}}{\partial \pi^{*}}\right)^{-1}
$$

To prove that this derivative is negative, I just need to show that $\frac{\partial V^{R}}{\partial p}$ is positive, since by Lemma $1 \frac{\partial V^{R}}{\partial \pi^{*}}>0$. I obtain

$$
\begin{aligned}
\frac{\partial V^{R}}{\partial p} & =\pi^{*} u^{\prime}\left(w^{H}\left(\pi^{*}\right)\right) \frac{\partial w^{H}}{\partial p}+\left(1-\pi^{*}\right) u^{\prime}\left(w^{L}\left(\pi^{*}\right)\right) \frac{\partial w^{L}}{\partial p} \\
& =\pi^{*}\left(1-\pi^{*}\right)\left[u^{\prime}\left(w^{L}\left(\pi^{*}\right)\right)-u^{\prime}\left(w^{H}\left(\pi^{*}\right)\right)\right](1-\varphi) A \geq 0
\end{aligned}
$$

since utility is concave and $w^{L}(\pi) \leq w^{H}(\pi)$. It follows that $\frac{\partial \pi^{*}}{\partial p} \leq 0$, with $\lim _{p \rightarrow 1} \frac{\partial \pi^{*}}{\partial p}=0$ since $\lim _{p \rightarrow 1} w^{H}(\pi)=\lim _{p \rightarrow 1} w^{L}(\pi)=w^{S}$ and $\lim _{p \rightarrow 0} \frac{\partial \pi^{*}}{\partial p}=-\infty$ since $\lim _{p \rightarrow 0} u^{\prime}\left(w^{L}\left(\pi^{*}\right)\right)=\infty$. 
The threshold ability varies with the technological parameters $A, \varphi$ and $B$ as follows

$$
\begin{aligned}
\frac{\partial \pi^{*}}{\partial A} & =-\frac{\partial V^{R}}{\partial A}\left(\frac{\partial V^{R}}{\partial \pi^{*}}\right)^{-1}<0 \\
\frac{\partial \pi^{*}}{\partial \varphi} & =-\frac{\partial V^{R}}{\partial \varphi}\left(\frac{\partial V^{R}}{\partial \pi^{*}}\right)^{-1}<0 \\
\frac{\partial \pi^{*}}{\partial B} & =\frac{\partial V^{S}}{\partial B}\left(\frac{\partial V^{R}}{\partial \pi^{*}}\right)^{-1}>0
\end{aligned}
$$

since

$$
\begin{aligned}
& \frac{\partial V_{t}^{R}}{\partial A}=\pi^{*} u^{\prime}\left(w_{i t}^{H}\right) \frac{\partial w^{H}}{\partial A}+\left(1-\pi^{*}\right) u^{\prime}\left(w_{i t}^{L}\right) \frac{\partial w^{L}}{\partial A} \\
& =\pi^{*} u^{\prime}\left(w_{i t}^{H}\right)[\varphi+\pi p(1-\varphi)+(1-p)(1-\varphi)] \\
& +\left(1-\pi^{*}\right) u^{\prime}\left(w_{i t}^{L}\right)[\varphi+\pi p(1-\varphi)]>0, \\
& \frac{\partial V_{t}^{R}}{\partial \varphi}=\pi^{*} u^{\prime}\left(w_{i t}^{H}\right) \frac{\partial w^{H}}{\partial \varphi}+\left(1-\pi^{*}\right) u^{\prime}\left(w_{i t}^{L}\right) \frac{\partial w^{L}}{\partial \varphi} \\
& =\left(1-\pi^{*}\right) u^{\prime}\left(w_{i t}^{H}\right) A p \pi^{*}+\left(1-\pi^{*}\right) u^{\prime}\left(w_{i t}^{L}\right) A\left(1-p \pi^{*}\right)>0
\end{aligned}
$$

and

$$
\frac{\partial V_{t}^{S}}{\partial B}=u^{\prime}(B-1)>0
$$

\section{Corollary 1}

The derivative of $\rho$ w.r.t. $\pi^{*}$ is

$$
\frac{\partial \rho}{\partial \pi^{*}}=-g\left(\pi^{*}\right) \leq 0
$$

The derivative of $\rho$ w.r.t. $\varphi$ is

$$
\frac{\partial \rho}{\partial \varphi}=\frac{\partial \pi^{*}}{\partial \varphi} \frac{\partial \rho}{\partial \pi^{*}} \geq 0
$$

since $\frac{\partial \pi^{*}}{\partial \varphi}<0$ by Lemma 2 .

The derivative of $\rho$ w.r.t. $B$ is

$$
\frac{\partial \rho}{\partial B}=\frac{\partial \pi^{*}}{\partial B} \frac{\partial \rho}{\partial \pi^{*}} \leq 0
$$

since $\frac{\partial \pi^{*}}{\partial B}>0$ by Lemma 2 . 
The derivative of $\rho$ w.r.t. $p$ is

$$
\frac{\partial \rho}{\partial p}=\frac{\partial \pi^{*}}{\partial p} \frac{\partial \rho}{\partial \pi^{*}} \geq 0
$$

since $\frac{\partial \pi^{*}}{\partial p}<0$ by Lemma 2 .

The derivative of $\rho$ w.r.t. $A$ is

$$
\frac{\partial \rho}{\partial A}=\frac{\partial \pi^{*}}{\partial A} \frac{\partial \rho}{\partial \pi^{*}} \geq 0
$$

since $\frac{\partial \pi^{*}}{\partial A}<0$ by Lemma 2 .

\section{Proposition 1}

The partial derivative of $\omega$ w.r.t. $p$, holding $\pi^{*}$ constant, is

$$
\left.\frac{\partial \omega}{\partial p}\right|_{\pi^{*}}=-\omega^{2} \frac{\pi^{*}(1-\varphi) A}{A-1} \leq 0
$$

The partial derivative of $\omega$ w.r.t. $\pi^{*}$, holding everything else constant, is

$$
\left.\frac{\partial \omega}{\partial \pi^{*}}\right|_{p}=-\omega^{2} \frac{p(1-\varphi) A}{A-1} \leq 0 .
$$

\section{Corollary 2}

The first part follows from Proposition 1 and Corollary 1.

The second part is easily proved by obtaining the derivative of $\omega$ w.r.t. $\rho$ :

$$
\left.\frac{d \omega}{d \rho}\right|_{p}=\left.\frac{\partial \omega}{\partial \pi^{*}}\right|_{p} / \frac{\partial \rho}{\partial \pi^{*}} .
$$

The first term is positive by Proposition 1 and the second is negative by Corollary 1 .

\section{Lemma 3}

The derivative of average entrepreneurial earnings w.r.t. $\pi^{*}$ is

$$
\frac{\partial \mathbb{E}[w]}{\partial \pi^{*}}=r g\left(\pi^{*}\right)\left[w^{S}-\pi^{*} w^{H}\left(\pi^{*}\right)-\left(1-\pi^{*}\right) w^{L}\left(\pi^{*}\right)\right] .
$$

This is non positive since, by risk aversion and the definition of $\pi^{*}, w^{S} \leq \pi^{*} w^{H}\left(\pi^{*}\right)-$ $\left(1-\pi^{*}\right) w^{L}\left(\pi^{*}\right)$.

\section{Proposition 2}


The partial derivative of $\operatorname{Var}(w)$ w.r.t. $p$ is

$$
\begin{aligned}
\frac{\partial V a r}{\partial p} & =\int_{\pi^{*}}^{1}\left\{2 \pi\left(w^{H}-\mathbb{E}[w]\right) \frac{\partial w^{H}}{\partial p}+2(1-\pi)\left(w^{L}-\mathbb{E}[w]\right) \frac{\partial w^{L}}{\partial p}\right\} g(\pi) d \pi \\
& =\int_{\pi^{*}}^{1}\left\{2 \pi w^{H} \frac{\partial w^{H}}{\partial p}+2(1-\pi) w^{L} \frac{\partial w^{L}}{\partial p}\right\} g(\pi) d \pi
\end{aligned}
$$

which becomes, after simplifying and replacing for $w^{H}, w^{L}, \frac{\partial w^{H}}{\partial p}=-(1-\pi)(1-\varphi) A$ and $\frac{\partial w^{L}}{\partial p}=\pi(1-\varphi) A$,

$$
\frac{\partial V a r}{\partial p}=-2(1-p)(1-\varphi)^{2} A^{2} \int_{\pi^{*}}^{1} \pi(1-\pi) g(\pi) d \pi \leq 0
$$

To prove that this derivative is higher the higher is the threshold ability $\pi^{*}$, I obtain the derivative of $\partial \operatorname{Var}(w) / \partial p$ w.r.t. $\pi^{*}$ and show that it is positive:

$$
\frac{\partial\left(\frac{\partial V a r}{\partial p}\right)}{\partial \pi^{*}}=2(1-p)(1-\varphi)^{2} A^{2} \pi^{*}\left(1-\pi^{*}\right) g(\pi) \geq 0 \text {. }
$$

\section{Corollary 3}

The first part follows from Proposition 2 and Corollary 1.

The second part is easily proved by obtaining the derivative of $\operatorname{Var}(w)$ w.r.t. $\rho$ :

$$
\left.\frac{d V a r}{d \rho}\right|_{p}=\left.\frac{\partial V a r}{\partial \pi^{*}}\right|_{p} / \frac{\partial \rho}{\partial \pi^{*}} \leq 0
$$

since the first term is positive by Proposition 1 and the second one negative by Corollary 1.

\section{B Simulation details}

This section describes step by step the procedure I followed for solving numerically the model of sections 2 and 3

1. Set values for the main parameters: $A=4, B=2, \varphi=\left[\begin{array}{lll}0.251 & 0.3 & 0.46\end{array}\right], r=1$.

2. Compute values for the parameters of the Lognormal distribution of abilities, $(\mu, \sigma)$, from Barro and Lee's (2000) data. The database provides observations for the percentages of the population aged 15 and above with no, primary, secondary and tertiary education $(l u, l p, l s, l h)$, along with the average year of each education level (pyr, syr, hyr). I compute the average years of schooling for people with primary, 
secondary and tertiary education $\left(q_{1}, q_{2}, q_{3}\right.$, respectively):

$$
q_{1}=\frac{p y r}{l p+l s+l h} ; q_{2}=q_{1}+\frac{s y r}{l s+l h} ; q_{3}=q_{1}+q_{2}+\frac{h y r}{l h} .
$$

The average years of schooling and their variance are then

$$
\begin{aligned}
E(Q) & =\sum_{i=1}^{3} l_{i} q_{i} \\
V(Q) & =\sum_{i=0}^{3} l_{i}\left(q_{i}-E(Q)\right)^{2},
\end{aligned}
$$

with $l_{0}=l u, l_{1}=l p, l_{2}=l s$ and $l_{3}=l h$. Finally, $\mu$ and $\sigma$ can be derived from the expressions for mean and variance of the Lognormal distribution:

$$
\begin{aligned}
E(Q) & =e^{\mu+\frac{\sigma^{2}}{2}} \\
V(Q) & =e^{2 \mu+2 \sigma^{2}}-e^{\mu+\sigma^{2}} .
\end{aligned}
$$

3. For each value of $\varphi$, compute the threshold ability with perfect investor protection $\left(\pi_{p=1}^{*}\right)$.

(a) Define a grid of 101 degrees of investor protection $p \in[0,1]$, and a grid of initial guesses for the threshold ability $\pi^{*} \in\left[\pi_{p=1}^{*}, 1\right]$, equally spaced by 0.00005 (the finer the grid, the better the approximation).

(b) Draw $\Pi=100001$ ability levels from a Lognormal $(\mu, \sigma)$ and sort them in ascending order. Identify the ability level $\pi_{.999}: G(\pi .999)=0.999$ and divide every $\pi \leq \pi .999$ by this figure. Replace all $\pi>\pi .999$ by 1 , so that the distribution is normalized to values included in $[0,1]$, and truncated in a way that makes the top 0.1 per cent of the population successful with certainty. Compute the Cdf of ability,

$$
G\left(\pi_{i}\right)=\frac{\# \text { of realizations } \pi \leq \pi_{i}}{\Pi} .
$$

(c) For each degree of investor protection $p$

i. compute $\pi^{*}(p)$ as the solution to the technology choice problem. In particular, recursively find the point in the grid of $\pi^{*}$ satisfying:

$$
\log (B-r)=\pi^{*} \log \left(w^{H}\left(\pi^{*}\right)\right)+\left(1-\pi^{*}\right) \log \left(w^{L}\left(\pi^{*}\right)\right)
$$

with $w^{H}\left(\pi^{*}\right)$ and $w^{L}\left(\pi^{*}\right)$ defined by (1) and (2) 
ii. for every ability $\pi$

A. draw the earning realization:

$$
\begin{aligned}
w & =\left\{\begin{array}{cc}
B-r & \pi<\pi^{*} \\
A\left[\pi^{*} p(1-\varphi)+\varphi+(1-p)(1-\varphi) \epsilon\right]-r & \pi \geq \pi^{*}
\end{array}\right. \\
\epsilon & \sim B i(N, \pi), \text { with } N=\# \text { of } \pi \geq \pi^{*} .
\end{aligned}
$$

B. sort $w$ and derive its cumulative density function as $F\left(w_{i}\right)=\frac{\# \text { of realizations } w \leq w_{i}}{\Pi}$

C. compute the variance of

D. compute the Lorenz Curve as $L\left(w_{m}\right)=\frac{\text { mean of } w \leq w_{m}}{\text { mean of } w} \frac{m}{\Pi}$ for $m=1,2, \ldots \Pi$

E. compute the Gini coefficient as Gini $=1-2 \sum_{m=1}^{\Pi} \frac{L\left(w_{m}\right)}{\Pi}$

iii. save the threshold, the variance and the Gini in $(1 \times p)$ vectors, $\boldsymbol{\pi}^{*}(p)$,

$\operatorname{Var}(w(p))$, and Gini $(p)$ 
Table A. Summary Statistics

\begin{tabular}{lcccc}
\hline \hline \multicolumn{1}{c}{ Variable } & Mean & $\begin{array}{c}\text { Std. } \\
\text { Dev. }\end{array}$ & Min & Max \\
\hline Gini & 37.489 & 8.487 & 26.569 & 58.254 \\
Investor Protection & 4.610 & 2.716 & 0 & 10 \\
Risk Taking & 0.676 & 0.358 & 0.037 & 1.571 \\
Log(Real p.c. GDP) & 9.347 & 0.835 & 7.562 & 10.361 \\
Schooling & 27.513 & 16.024 & 1.55 & 71.725 \\
Gov't & & & & \\
expenditure/GDP & 0.062 & 0.053 & 0.015 & 0.329 \\
Trade/GDP & 0.158 & 0.072 & 0.043 & 0.494 \\
\hline \hline
\end{tabular}

Table 1. Investor Protection and Income Inequality Cross-section, 1980-2000, OLS

\begin{tabular}{|c|c|c|c|c|c|c|c|c|c|}
\hline Dep. variable: & Gini_8000 & Gini_8000 & Gini_8000 & Gini_8000 & Gini_8000 & Gini_8000 & Gini_last & Gini_last & Gini_last \\
\hline \multirow[t]{2}{*}{ Investor protection (IP) } & 0.174 & $1.690^{*}$ & $2.140 \star \star$ & $1.976^{\star \star}$ & & & 0.232 & $1.807^{*}$ & $2.047^{\star *}$ \\
\hline & {$[0.472]$} & [0.893] & [0.791] & {$[0.834]$} & & & [0.511] & [0.982] & [0.965] \\
\hline \multirow[t]{2}{*}{$I P * I P \_h i g h$} & & $-1.266^{*}$ & $-1.397^{\star \star}$ & $-1.327^{\star \star}$ & & & & $-1.316^{\star}$ & $-1.336^{\star}$ \\
\hline & & [0.659] & [0.642] & [0.628] & & & & [0.755] & {$[0.757]$} \\
\hline \multirow[t]{2}{*}{ Antidir (AD) } & & & & & 0.809 & $3.028^{*}$ & & & \\
\hline & & & & & {$[1.000]$} & [1.653] & & & \\
\hline \multirow[t]{2}{*}{$A D * A D$ high } & & & & & & -1.592 & & & \\
\hline & & & & & & {$[1.036]$} & & & \\
\hline \multirow[t]{2}{*}{ Schooling } & 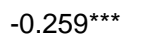 & $-0.255^{\star \star \star}$ & -0.083 & -0.05 & $-0.262^{\star \star \star}$ & $-0.255^{\star \star \star}$ & $-0.281^{\star \star *}$ & $-0.276^{\star \star \star}$ & -0.022 \\
\hline & {$[0.077]$} & {$[0.071]$} & [0.091] & {$[0.109]$} & {$[0.075]$} & {$[0.074]$} & [0.094] & [0.091] & [0.133] \\
\hline \multirow[t]{2}{*}{ log(Real GDP p.c.) } & & & $114.792^{\star \star}$ & $120.132^{\star \star}$ & & & & & $140.146^{\star \star \star}$ \\
\hline & & & [47.418] & [46.003] & & & & & {$[46.254]$} \\
\hline \multirow[t]{2}{*}{$\log ($ Real GDP p.c.)^2 } & & & $-6.520^{\star \star}$ & $-6.863^{\star \star \star}$ & & & & & $-8.031^{\star \star \star}$ \\
\hline & & & [2.597] & [2.513] & & & & & [2.522] \\
\hline \multirow[t]{2}{*}{ Gov't expenditure/GDP } & & & & 3.467 & & & & & 3.690 \\
\hline & & & & [14.379] & & & & & [17.935] \\
\hline \multirow[t]{2}{*}{ Trade/GDP } & & & & -16.495 & & & & & $-25.578^{\star}$ \\
\hline & & & & [12.936] & & & & & [14.864] \\
\hline Observations & 45 & 45 & 45 & 45 & 45 & 45 & 45 & 45 & 45 \\
\hline R-squared & 0.228 & 0.279 & 0.477 & 0.494 & 0.241 & 0.284 & 0.205 & 0.248 & 0.487 \\
\hline
\end{tabular}

Note: dipendent variable is the Gini coefficient of the income distribution, expressed in period average (Gini_8000) and in the last available observation (Gini_last). Among the regressors, Investor Protection is a de jure index scaled from 0 to 10 , IP_high is a dummy for investor protection higher than the median, Antidir is a de jure index of anti directors' self dealing measures scaled between 0 and $6, A D \_$high is a dummy for Antidir higher than 3, Schooling is percentage of population aged above 25 years with completed secondary education, Trade is Import+Export. All regressors are expressed in period average. Regressions are performed with OLS. Robust standard errors are reported in brackets. ${ }^{\star \star \star},{ }^{* \star}$ and ${ }^{*}$ denote significance at 1,5 and 10 per cent level of confidence. 
Table 2. Investor Protection and Risk Taking

Cross-section, 1980-2000

\begin{tabular}{|c|c|c|c|c|c|c|}
\hline & $\begin{array}{l}\text { Risk } \\
\text { Taking }\end{array}$ & $\begin{array}{l}\text { Investor } \\
\text { protection }\end{array}$ & $\begin{array}{l}\text { Risk } \\
\text { Taking }\end{array}$ & $\begin{array}{c}\text { Risk } \\
\text { Taking }\end{array}$ & Antidir & $\begin{array}{c}\text { Risk } \\
\text { Taking }\end{array}$ \\
\hline Investor protection & $\begin{array}{l}0.058^{\star \star \star} \\
{[0.021]}\end{array}$ & & $\begin{array}{l}0.064^{\star \star} \\
{[0.028]}\end{array}$ & & & \\
\hline Antidir & & & & $\begin{array}{l}0.079^{\star} \\
{[0.043]}\end{array}$ & & $\begin{array}{l}0.141^{* *} \\
{[0.066]}\end{array}$ \\
\hline $\log ($ Real GDP p.c.) & $\begin{array}{l}-0.045 \\
{[0.070]}\end{array}$ & $\begin{array}{l}0.187 \\
{[0.579]}\end{array}$ & $\begin{array}{l}-0.038 \\
{[0.084]}\end{array}$ & $\begin{array}{l}-0.064 \\
{[0.071]}\end{array}$ & $\begin{array}{l}0.025 \\
{[0.307]}\end{array}$ & $\begin{array}{l}-0.027 \\
{[0.094]}\end{array}$ \\
\hline Efficiency judiciary & $\begin{array}{l}0.053 \\
{[0.033]}\end{array}$ & $\begin{array}{l}0.091 \\
{[0.252]}\end{array}$ & $\begin{array}{l}0.048 \\
{[.036]}\end{array}$ & $\begin{array}{l}0.067^{\star} \\
{[0.034]}\end{array}$ & $\begin{array}{l}0.042 \\
{[0.134]}\end{array}$ & $\begin{array}{l}0.047 \\
{[0.039]}\end{array}$ \\
\hline UK legal origin & & $\begin{array}{l}2.652^{\star \star} \\
{[1.205]}\end{array}$ & & & $\begin{array}{l}1.223^{\star} \\
{[0.638]}\end{array}$ & \\
\hline French legal origin & & $\begin{array}{l}-1.272 \\
{[1.272]}\end{array}$ & & & $\begin{array}{l}-0.583 \\
{[0.675]}\end{array}$ & \\
\hline German legal origin & & $\begin{array}{l}-1.354 \\
{[1.389]}\end{array}$ & & & $\begin{array}{l}-0.749 \\
{[0.736]}\end{array}$ & \\
\hline Observations & 45 & 45 & 45 & 45 & 45 & 45 \\
\hline R-squared & 0.326 & 0.497 & 0.324 & 0.241 & 0.433 & 0.192 \\
\hline Estimation & OLS & 2SLS - first & $\begin{array}{l}\text { 2SLS - } \\
\text { second }\end{array}$ & OLS & 2SLS - first & $\begin{array}{l}\text { 2SLS - } \\
\text { second }\end{array}$ \\
\hline $\begin{array}{l}\text { F-test } \\
\text { [p-value] }\end{array}$ & & $\begin{array}{l}9.13 \\
{[0.000]}\end{array}$ & & & $\begin{array}{l}7.15 \\
{[0.001]}\end{array}$ & \\
\hline Sargan test & & 3.28 & & & 2.41 & \\
\hline [p-value] & & [0.190] & & & {$[0.300]$} & \\
\hline
\end{tabular}

Note. The dependent variable is risk taking, proxied by stock market capitalization as a ratio of total credit to the private sector, in columns 1, 3, 4 and 6; the index of investor protection (scaled from 0 to 10) in column 2; and the anti directors' self-dealing measures (Antidir, scaled from 0 to 6 ) in column 5 . Among the regressors, Efficiency of the judiciary is a de jure index scaled from 0 to 10; UK, French and German legal origins are dummies. All variables are expressed in period average. OLS estimates in columns 1 and 4, 2SLS instrumental variable estimates in columns 2-3 and 5-6. Robust standard errors are reported in brackets. ${ }^{* * *},{ }^{* *}$ and ${ }^{*}$ denote significance at 1,5 and 10 per cent level of confidence. 
Table 3. Investor Protection, Risk Taking and Income Inequality

Panel, 1976-2000, Random Effects

Panel A. Investor Protection (IP)

\begin{tabular}{|c|c|c|c|c|c|c|c|}
\hline Investor protection (IP) & $\begin{array}{l}0.096 \\
{[0.511]}\end{array}$ & $\begin{array}{l}1.884^{\star} \\
{[1.018]}\end{array}$ & $\begin{array}{l}-0.077 \\
{[0.482]}\end{array}$ & $\begin{array}{l}1.692^{\star} \\
{[0.915]}\end{array}$ & $\begin{array}{l}0.339 \\
{[0.488]}\end{array}$ & $\begin{array}{l}0.405 \\
{[0.455]}\end{array}$ & $\begin{array}{l}0.548 \\
{[0.456]}\end{array}$ \\
\hline$I P * I P \_h i g h$ & & $\begin{array}{l}-1.479 * \\
{[0.796]}\end{array}$ & & $\begin{array}{l}-1.466^{\star \star} \\
{[0.721]}\end{array}$ & & & \\
\hline Risk Taking (RT) & & & $\begin{array}{l}3.873^{\star \star \star} \\
{[1.350]}\end{array}$ & $\begin{array}{l}3.932 * \star \star \\
{[1.373]}\end{array}$ & $\begin{array}{l}8.256^{\star \star \star} \\
{[2.256]}\end{array}$ & $\begin{array}{l}6.963^{\star \star \star} \\
{[2.577]}\end{array}$ & $\begin{array}{l}8.261^{\star \star \star} \\
{[2.114]}\end{array}$ \\
\hline $\mathrm{RT}^{\star} \mathrm{IP}$ & & & & & $\begin{array}{l}-0.776^{\star \star} \\
{[0.375]}\end{array}$ & $\begin{array}{l}-0.626 \\
{[0.446]}\end{array}$ & \\
\hline$R T^{*} I P \_$high & & & & & & & $\begin{array}{l}-6.289 * \star \star \\
{[2.374]}\end{array}$ \\
\hline Schooling & $\begin{array}{l}-17.917^{\star \star \star} \\
{[4.855]}\end{array}$ & $\begin{array}{l}-17.472^{\star \star \star} \\
{[4.767]}\end{array}$ & $\begin{array}{l}-20.980 \star \star \star \\
{[4.603]}\end{array}$ & $\begin{array}{l}-20.505^{\star \star \star} \\
{[4.505]}\end{array}$ & $\begin{array}{l}-21.340 * \star \star \\
{[4.637]}\end{array}$ & $\begin{array}{l}-12.516^{\star \star} \\
{[5.960]}\end{array}$ & $\begin{array}{l}-13.590 * \star \\
{[6.055]}\end{array}$ \\
\hline $\log ($ Real GDP p.c.) & & & & & & $\begin{array}{l}52.308 * * \\
{[23.726]}\end{array}$ & $\begin{array}{l}48.474^{\star \star} \\
{[22.935]}\end{array}$ \\
\hline log(Real GDP p.c.) squared & & & & & & $\begin{array}{l}-3.092^{\star \star} \\
{[1.343]}\end{array}$ & $\begin{array}{l}-2.865^{\star \star} \\
{[1.301]}\end{array}$ \\
\hline Gov't expenditure/GDP & & & & & & $\begin{array}{l}-7.102 \\
{[9.058]}\end{array}$ & $\begin{array}{l}-7.146 \\
{[9.274]}\end{array}$ \\
\hline Trade/GDP & & & & & & $\begin{array}{l}-0.845 \\
{[1.613]}\end{array}$ & $\begin{array}{l}-0.944 \\
{[1.570]}\end{array}$ \\
\hline Observations & 85 & 85 & 85 & 85 & 85 & 85 & 85 \\
\hline Countries & 41 & 41 & 41 & 41 & 41 & 41 & 41 \\
\hline R-squared & 0.166 & 0.188 & 0.279 & 0.306 & 0.27 & 0.419 & 0.45 \\
\hline
\end{tabular}

Note: All observations refer to non-overlapping 5-year periods. Dependent variable is the Gini coefficient of the income distribution observed in the last available year. Regressors, defined in Tables 1 and 2, are period averages. Regressions are performed with Least Squares. Robust standard errors are reported in brackets. ${ }^{* \star}$, ** and * denote significance at 1,5 and 10 per cent level of confidence. 
Table 3. Investor Protection, Risk Taking and Income Inequality

Panel, 1976-2000, Random Effects

Panel B. Anti Directors' self dealing (AD)

\begin{tabular}{|c|c|c|c|c|c|c|c|}
\hline Antidir (AD) & $\begin{array}{l}0.782 \\
{[0.978]}\end{array}$ & $\begin{array}{l}2.986^{\star} \\
{[1.800]}\end{array}$ & $\begin{array}{l}-0.532 \\
{[1.002]}\end{array}$ & $\begin{array}{l}2.873^{\star} \\
{[1.618]}\end{array}$ & $\begin{array}{l}1.782 \\
{[1.202]}\end{array}$ & $\begin{array}{l}1.902^{\star} \\
{[1.117]}\end{array}$ & $\begin{array}{l}1.647 \\
{[1.065]}\end{array}$ \\
\hline$A D * A D$ _high & & $\begin{array}{l}-1.611 \\
{[1.207]}\end{array}$ & & $\begin{array}{l}-1.770 \\
{[1.105]}\end{array}$ & & & \\
\hline Risk Taking (RT) & & & $\begin{array}{l}3.767^{\star \star \star} \\
{[1.372]}\end{array}$ & $\begin{array}{l}3.932^{\star \star \star} \\
{[1.438]}\end{array}$ & $\begin{array}{l}11.344^{\star \star \star} \\
{[2.580]}\end{array}$ & $\begin{array}{l}10.548^{\star \star \star} \\
{[2.708]}\end{array}$ & $\begin{array}{l}6.059 * * * \\
{[2.041]}\end{array}$ \\
\hline $\mathrm{RT}{ }^{\star} \mathrm{AD}$ & & & & & $\begin{array}{l}-2.220^{\star \star \star} \\
{[0.804]}\end{array}$ & $\begin{array}{l}-2.117^{\star \star} \\
{[0.869]}\end{array}$ & \\
\hline $\mathrm{RT}^{*} \mathrm{AD}$ _high & & & & & & & $\begin{array}{l}-5.437^{*} \\
{[2.795]}\end{array}$ \\
\hline Schooling & $\begin{array}{l}-18.324^{\star \star \star} \\
{[4.980]}\end{array}$ & $\begin{array}{l}-18.087^{\star \star \star} \\
{[4.941]}\end{array}$ & $\begin{array}{l}-21.317^{\star \star \star} \\
{[4.689]}\end{array}$ & $\begin{array}{l}-21.232^{\star \star \star} \\
{[4.671]}\end{array}$ & $\begin{array}{l}-22.506^{\star \star \star} \\
{[4.750]}\end{array}$ & $\begin{array}{l}-14.672^{\star \star} \\
{[5.791]}\end{array}$ & $\begin{array}{l}-15.355^{\star \star \star} \\
{[5.760]}\end{array}$ \\
\hline log(Real GDP p.c.) & & & & & & $\begin{array}{l}56.284^{\star *} \\
{[23.435]}\end{array}$ & $\begin{array}{l}53.173^{\star *} \\
{[23.017]}\end{array}$ \\
\hline log(Real GDP p.c.) squared & & & & & & $\begin{array}{l}-3.292^{\star \star} \\
{[1.317]}\end{array}$ & $\begin{array}{l}-3.105^{\star \star} \\
{[1.294]}\end{array}$ \\
\hline Gov't expenditure/GDP & & & & & & $\begin{array}{l}-5.918 \\
{[9.380]}\end{array}$ & $\begin{array}{l}-6.082 \\
{[9.053]}\end{array}$ \\
\hline Trade/GDP & & & & & & $\begin{array}{l}-1.152 \\
{[1.509]}\end{array}$ & $\begin{array}{l}-0.549 \\
{[1.630]}\end{array}$ \\
\hline Observations & 85 & 85 & 85 & 85 & 85 & 85 & 85 \\
\hline Countries & 41 & 41 & 41 & 41 & 41 & 41 & 41 \\
\hline R-squared & 0.151 & 0.155 & 0.26 & 0.279 & 0.228 & 0.408 & 0.403 \\
\hline
\end{tabular}

Note: All observations refer to non-overlapping 5-year periods. Dependent variable is the Gini coefficient of the income distribution observed in the last available year. Regressors, defined in Tables 1 and 2, are period averages. Regressions are performed with Least Squares. Robust standard errors are reported in brackets. ${ }^{* \star}$, ** and * denote significance at 1,5 and 10 per cent level of confidence. 
Table 4. Risk Taking, Risk Sharing and Income Inequality

Panel, 1976-2000, Fixed and Random Effects

Panel A. Investor Protection (IP)

\begin{tabular}{|c|c|c|c|c|c|c|}
\hline Risk Taking (RT) & $\begin{array}{l}7.531^{\star \star \star} \\
{[2.477]}\end{array}$ & $\begin{array}{l}7.549 * \star \star \\
{[2.234]}\end{array}$ & $\begin{array}{l}5.981^{\star \star} \\
{[2.769]}\end{array}$ & $\begin{array}{l}7.060 \star \star \star \\
{[2.438]}\end{array}$ & $\begin{array}{l}7.586^{\star \star \star} \\
{[2.080]}\end{array}$ & $\begin{array}{l}7.128 \star \star \star \\
{[2.237]}\end{array}$ \\
\hline $\mathrm{RT}^{*} \mathrm{IP}$ & $\begin{array}{l}-0.633 \\
{[0.393]}\end{array}$ & $\begin{array}{l}-0.822^{\star \star} \\
{[0.338]}\end{array}$ & $\begin{array}{l}-0.414 \\
{[0.443]}\end{array}$ & $\begin{array}{l}-0.861^{\star *} \\
{[0.360]}\end{array}$ & & \\
\hline$R T^{\star} \mid P \_h i g h$ & & & & & $\begin{array}{l}-4.991^{\star \star} \\
{[2.211]}\end{array}$ & $\begin{array}{l}-6.205^{\star *} \\
{[2.525]}\end{array}$ \\
\hline Schooling & $\begin{array}{l}-20.830^{\star \star \star} \\
{[4.762]}\end{array}$ & $\begin{array}{l}-15.906^{\star \star \star} \\
{[5.436]}\end{array}$ & $\begin{array}{l}-11.389 * \\
{[6.035]}\end{array}$ & $\begin{array}{l}-16.392^{\star *} \\
{[7.803]}\end{array}$ & $\begin{array}{l}-12.052^{*} \\
{[6.181]}\end{array}$ & $\begin{array}{l}-15.818^{*} \\
{[8.011]}\end{array}$ \\
\hline log(Real GDP p.c.) & & & $\begin{array}{l}48.419 \star \star \\
{[22.441]}\end{array}$ & $\begin{array}{l}4.115 \\
{[23.804]}\end{array}$ & $\begin{array}{l}43.240 * \\
{[22.073]}\end{array}$ & $\begin{array}{l}-6.221 \\
{[24.089]}\end{array}$ \\
\hline log(Real GDP p.c.) squared & & & $\begin{array}{l}-2.884^{\star \star} \\
{[1.279]}\end{array}$ & $\begin{array}{l}-0.348 \\
{[1.429]}\end{array}$ & $\begin{array}{l}-2.585^{\star \star} \\
{[1.260]}\end{array}$ & $\begin{array}{l}0.23 \\
{[1.443]}\end{array}$ \\
\hline Gov't expenditure/GDP & & & $\begin{array}{l}-7.143 \\
{[8.925]}\end{array}$ & $\begin{array}{l}-0.725 \\
{[9.284]}\end{array}$ & $\begin{array}{l}-7.503 \\
{[9.085]}\end{array}$ & $\begin{array}{l}1.184 \\
{[9.491]}\end{array}$ \\
\hline Trade/GDP & & & $\begin{array}{l}-0.902 \\
{[1.556]}\end{array}$ & $\begin{array}{l}5.067 \\
{[3.647]}\end{array}$ & $\begin{array}{l}-0.937 \\
{[1.518]}\end{array}$ & $\begin{array}{l}4.463 \\
{[3.516]}\end{array}$ \\
\hline Observations & 85 & 85 & 85 & 85 & 85 & 85 \\
\hline Countries & 41 & 41 & 41 & 41 & 41 & 41 \\
\hline R-squared & 0.277 & 0.203 & 0.421 & 0.234 & 0.44 & 0.269 \\
\hline Country FE & No & Yes & No & Yes & No & Yes \\
\hline \multicolumn{7}{|c|}{ Panel B. Anti Directors' self dealing (AD) } \\
\hline Risk Taking (RT) & $\begin{array}{l}9.301^{\star \star \star} \\
{[2.359]}\end{array}$ & $\begin{array}{l}11.236^{\star \star \star} \\
{[2.703]}\end{array}$ & $\begin{array}{l}8.005^{\star \star \star} \\
{[2.470]}\end{array}$ & $\begin{array}{l}10.468^{\star \star \star} \\
{[2.627]}\end{array}$ & $\begin{array}{l}5.580 \star \star \star \\
{[1.937]}\end{array}$ & $\begin{array}{l}5.559 \star \star \star \\
{[1.508]}\end{array}$ \\
\hline$R T^{\star} A D$ & $\begin{array}{l}-1.577^{\star \star} \\
{[0.703]}\end{array}$ & $\begin{array}{l}-2.415^{\star \star \star} \\
{[0.857]}\end{array}$ & $\begin{array}{l}-1.238^{\star} \\
{[0.731]}\end{array}$ & $\begin{array}{l}-2.328^{\star \star \star} \\
{[0.860]}\end{array}$ & & \\
\hline $\mathrm{RT}^{*} \mathrm{AD}$ _high & & & & & $\begin{array}{l}-3.594 \\
{[2.300]}\end{array}$ & $\begin{array}{l}-6.021^{\star *} \\
{[2.408]}\end{array}$ \\
\hline Schooling & $\begin{array}{l}-21.380^{\star \star *} \\
{[4.729]}\end{array}$ & $\begin{array}{l}-17.799 * \star \star \\
{[5.244]}\end{array}$ & $\begin{array}{l}-12.487^{\star \star} \\
{[5.917]}\end{array}$ & $\begin{array}{l}-17.084^{\star \star} \\
{[7.466]}\end{array}$ & $\begin{array}{l}-13.217^{\star *} \\
{[5.866]}\end{array}$ & $\begin{array}{l}-17.045^{\star *} \\
{[7.522]}\end{array}$ \\
\hline log(Real GDP p.c.) & & & $\begin{array}{l}47.146 * \star \\
{[21.997]}\end{array}$ & $\begin{array}{l}8.608 \\
{[22.425]}\end{array}$ & $\begin{array}{l}45.866^{\star \star} \\
{[21.861]}\end{array}$ & $\begin{array}{l}5.482 \\
{[24.076]}\end{array}$ \\
\hline log(Real GDP p.c.) squared & & & $\begin{array}{l}-2.804^{\star \star} \\
{[1.253]}\end{array}$ & $\begin{array}{l}-0.569 \\
{[1.326]}\end{array}$ & $\begin{array}{l}-2.721^{\star \star} \\
{[1.245]}\end{array}$ & $\begin{array}{l}-0.405 \\
{[1.429]}\end{array}$ \\
\hline Gov't expenditure/GDP & & & $\begin{array}{l}-7.021 \\
{[9.053]}\end{array}$ & $\begin{array}{l}1.135 \\
{[9.083]}\end{array}$ & $\begin{array}{l}-7.129 \\
{[8.852]}\end{array}$ & $\begin{array}{l}0.283 \\
{[9.224]}\end{array}$ \\
\hline Trade/GDP & & & $\begin{array}{l}-1.354 \\
{[1.415]}\end{array}$ & $\begin{array}{l}2.860 \\
{[2.474]}\end{array}$ & $\begin{array}{l}-0.976 \\
{[1.511]}\end{array}$ & $\begin{array}{l}3.520 \\
{[2.776]}\end{array}$ \\
\hline Observations & 85 & 85 & 85 & 85 & 85 & 85 \\
\hline Countries & 41 & 41 & 41 & 41 & 41 & 41 \\
\hline R-squared & 0.243 & 0.295 & 0.399 & 0.307 & 0.398 & 0.294 \\
\hline Country FE & No & Yes & No & Yes & No & Yes \\
\hline
\end{tabular}

Note: All observations refer to non-overlapping 5-year periods. Dependent variable is the Gini coefficient of the income distribution observed in the last available year. Regressors, defined in Tables 1 and 2, are period averages. Regressions are performed with Least Squares. Robust standard errors are reported in brackets. ${ }^{\star \star *}$, ${ }^{\star *}$ and * denote significance at 1,5 and 10 per cent level of confidence. 